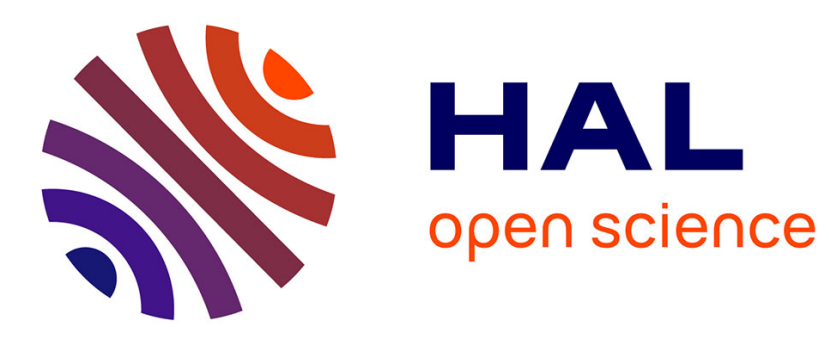

\title{
Peru-Chile upwelling dynamics under climate change
}

Véra Oerder, François Colas, Vincent Echevin, Francis Codron, Jorge Tam, Ali Belmadani

\section{To cite this version:}

Véra Oerder, François Colas, Vincent Echevin, Francis Codron, Jorge Tam, et al.. Peru-Chile upwelling dynamics under climate change. Journal of Geophysical Research. Oceans, 2015, 120 (2), pp.11521172. 10.1002/2014JC010299 . hal-01132836

\section{HAL Id: hal-01132836 https://hal.sorbonne-universite.fr/hal-01132836}

Submitted on 18 Mar 2015

HAL is a multi-disciplinary open access archive for the deposit and dissemination of scientific research documents, whether they are published or not. The documents may come from teaching and research institutions in France or abroad, or from public or private research centers.
L'archive ouverte pluridisciplinaire HAL, est destinée au dépôt et à la diffusion de documents scientifiques de niveau recherche, publiés ou non, émanant des établissements d'enseignement et de recherche français ou étrangers, des laboratoires publics ou privés. 


\section{Journal of Geophysical Research: Oceans}

\section{RESEARCH ARTICLE Peru-Chile upwelling dynamics under climate change}

\subsection{2/2014JC010299}

Key Points:

- Climate change impact on the nearshore circulation

- Modification in the upwelling

intensity and its geostrophic compensation

- Modification in the upwelled water sources

Correspondence to:

V. Oerder,

vera.oerder@locean-ipsl.upmc.fr

Citation:

Oerder, V., F. Colas, V. Echevin,

F. Codron, J. Tam, and A. Belmadani (2015), Peru-Chile upwelling dynamics under climate change, J. Geophys. Res. Oceans, 120, doi:10.1002/

2014JC010299.

Received 9 JUL 2014

Accepted 18 JAN 2015

Accepted article online 27 JAN 2015

\author{
Véra Oerder1, Francois Colas ${ }^{1}$, Vincent Echevin ${ }^{1}$, Francis Codron 1,2, Jorge Tam ${ }^{3}$, and Ali Belmadani, ${ }^{4,5}$ \\ ${ }^{1}$ Sorbonne Universités (UPMC, Univ Paris 06)-CNRS-IRD-MNHN, LOCEAN Laboratory, Paris, France, ${ }^{2}$ LMD, Sorbonne \\ Universités (UPMC, Univ Paris 06), Paris, France, ${ }^{3}$ IMARPE, Esquina Gamarra y General Valle S/N Chucuito Callao, Peru, \\ ${ }^{4}$ Department of Geophysics, Faculty of Physical and Mathematical Sciences, University of Concepcion, Chile, ${ }^{5}$ Millennium \\ Institute of Oceanography, University of Concepcion, Chile
}

\begin{abstract}
The consequences of global warming on the Peru-Chile Current System (PCCS) ocean circulation are examined with a high-resolution, eddy-resolving regional oceanic model. We performed a dynamical downscaling of climate scenarios from the IPSL-CM4 Coupled General Circulation Model (CGCM), corresponding to various levels of $\mathrm{CO}_{2}$ concentrations in the atmosphere. High-resolution atmospheric forcing for the regional ocean model are obtained from the IPSL atmospheric model run on a stretched grid with increased horizontal resolution in the PCCS region. When comparing future scenarios to preindustrial (PI) conditions, the circulation along the Peru and Chile coasts is strongly modified by changes in surface winds and increased stratification caused by the regional warming. While the coastal poleward undercurrent is intensified, the surface equatorial coastal jet shoals and the nearshore mesoscale activity are reinforced. Reduction in alongshore wind stress and nearshore wind stress curl drive a year-round reduction in upwelling intensity off Peru. Modifications in geostrophic circulation mitigate this upwelling decrease in late austral summer. The depth of the upwelling source waters becomes shallower in warmer conditions, which may have a major impact on the system's biological productivity.
\end{abstract}

\section{Introduction}

The South-East Pacific (SEP) hosts the most productive Eastern Boundary Upwelling System (EBUS) in term of fisheries [Chavez et al., 2008]: The Humboldt Current System or Peru-Chile Current System (PCCS). The intense biological activity found along the South American west coasts is due to a year-round wind-forced upwelling, which cools and enriches the surface waters. Two causes are responsible for the intense and steady coastal upwelling: first, alongshore equatorward wind stress generates the divergence of Ekman currents at the coast, which is compensated by a vertical upward flow. Second, an alongshore wind decrease (also called "dropoff") occurs over a few hundred kilometers in the cross-shore direction, due to coastal orography, land/sea transition in the surface drag and air-sea interaction over cool water [e.g., Capet et al., 2004; Boé et al., 2011]. It results in negative wind stress curl driving Ekman pumping [e.g., Bakun and Nelson, 1991; Albert et al., 2010].

Climate change in EBUS has been first questioned by Bakun [1990] using shipboard measurements of nearshore surface winds. He showed that upwelling-favorable winds had increased over the period 1955-1988 in several EBUS including the PCCS, and considered that this trend was due to global warming and would thus go on in the future. The proposed mechanism is the following: as ground temperature would increase more than sea surface temperature under climate change, this would lead to a lower pressure over land and an enhancement of the cross-shore pressure gradient, leading to a geostrophic alongshore wind intensification. Climate change-induced modifications of the SEP atmospheric circulation have been studied using various CGCMs. Most 4th Assessment Report (AR4) Intergovernmental Panel on Climate Change (IPCC) CGCMs predict a SEP anticyclone intensification and a southward displacement of its center [Falvey and Garreaud, 2009; Goubanova et al., 2011, hereafter GO2011; Echevin et al. 2012, hereafter EC2012; Belmadani et al., 2014, hereafter BEL2014]. This southward shift is part of a broader poleward expansion of the subtropics [Kang and Lu, 2012]. As a consequence, coastal winds have become stronger during the upwelling-favorable season along the Chile coast [Garreaud and Falvey, 2008, BEL2014], which is consistent with Bakun's [1990] hypothesis. However, CGCMs also predict a decrease in easterlies and Walker cell intensity [Vecchi and Soden, 2007], so that the situation at the Peruvian coast is unclear: although the SEP anticyclone is reinforced, its southward displacement could result in a coastal wind decrease off Peru. In any case, CGCMs spatial resolution is generally 
too low (typically more than $100-200 \mathrm{~km}$ ) to provide a realistic simulation of the regional climate in the PCCS. The influence of the steep topography of the Andes and of the oceanic slope cannot be accurately simulated. In order to reach a higher spatial resolution, regional downscaling must be considered. Garreaud and Falvey [2008] studied wind changes off Chile using a regional atmospheric model (PRECIS) [Jones et al., 2004] for central Chile $\left[18^{\circ} \mathrm{S}-57^{\circ} \mathrm{S}\right]$, forced by the Hadley Centre Atmospheric Model version3 (HadCM3) climate model under two scenarios (A2 and B2 from Special Report on Emissions Scenarios (SRES)] [see Nakicenovic et al., 2000], and confirmed the wind intensification off Chile. GO2011 performed a statistical downscaling of the IPSL-CM4 surface winds along the Peru and Chile coasts under idealized preindustrial (PI), doubling and quadrupling $\mathrm{CO}_{2}$ scenarios. Their results confirmed the wind strengthening off $\mathrm{Chile}$, whereas they show a decrease in the annual mean off Peru, consequence of an austral summer decrease and a moderate winter increase. Evolution under global warming of the ocean circulation in the PCCS has also been assessed. Aiken et al. [2011] studied the influence of wind changes on the coastal ocean dynamics off Chile and its impact on fish larvae dispersal. They performed high-resolution regional oceanic simulations using the dynamically downscaled winds from the A2 SRES climate scenario of the HadCM3 [Garreaud and Falvey, 2008], and present conditions for heat and salt surface fluxes and ocean boundary conditions. Their results showed that the alongshore wind increase off Chile led to a year-round upwelling intensification and nearshore sea surface temperature (SST) decrease. In a comparable study, EC2012 studied the ocean circulation changes in the PCCS using a regional model driven by the GO2011 statistically downscaled atmospheric forcing and oceanic boundary conditions from the IPSL-CM4 CGCM [Marti et al., 2010], under three climate scenarios of increasing warming. Off Peru, they found an increase in surface stratification caused by the intense large-scale heating (from both atmospheric and boundary conditions). The poleward coastal undercurrent (also named Peru Chile Undercurrent, hereafter PCUC) was enhanced and the equatorward surface coastal Peru-Chile current (hereafter PCC) became thinner, resulting in an increased vertical shear and mesoscale turbulence. Upwelling decreased during austral summer and slightly intensified during winter. Off Chile, upwelling increased strongly during austral spring and summer.

In the present study, the sensitivity of the ocean circulation to the atmospheric forcing is investigated with regional oceanic simulations forced by an atmospheric dynamical downscaling of the IPSL-CM4 CGCM. The same regional oceanic model and boundary conditions as in EC2012 are used. However, in our study, the air/sea interface is forced by an atmospheric model resolving physical processes at $\sim 50 \mathrm{~km}$ horizontal resolution in the PCCS region while GO2011 forcing fields used by EC2012 were computed from a statistical downscaling of the IPSL-CM4. Note that GO2011 results were based on a statistical relation between the large-scale NCEP reanalysis fields and surface observations (QuikSCAT scatterometer winds), computed during a short, recent period (2000-2008) and then applied to the IPSL large-scale model fields for climatechange scenarios. The atmospheric simulations used in our present study have been described in BEL2014. We compare the results of these new simulations with those of EC2012, focusing on changes in the central Peru $\left(\mathrm{CP}, 7^{\circ} \mathrm{S}-13^{\circ} \mathrm{S}\right)$ coastal circulation. We provide detailed diagnostics (not included in EC2012) on the coastal upwelling dynamics, its modulation by cross-shore geostrophic flow, and the depth and location of upwelled water sources under different climate conditions.

The paper is organized as follows: in section 2, the modeling methodology is described. In section 3, the realism of the control (i.e., current climate) simulations is assessed and results from the climate change simulations are presented in section 4. Finally, the main findings are discussed in section 5.

\section{Methodology}

\subsection{IPSL-CM4 CGCM and Climate Scenarios}

IPSL-CM4 couples an atmospheric model named LMDz [Hourdin et al., 2006] with the NEMO oceanic component [Madec et al., 1998] in its ORCA2 configuration [Marti et al., 2010]. Figure 1 (left) represents this CGCM. The atmospheric horizontal resolution is $4.9^{\circ} \times 2.4^{\circ}$ while the oceanic is $2^{\circ}$ and gets refined to $1^{\circ}$ near the equator. ORCA2 has 31 vertical levels.

Using the same CGCM as in EC2012 allows us to compare the impact of two different atmospheric downscaling methods on the ocean circulation. In addition, IPSL-CM4 presents various advantages, mentioned by GO2011, EC2012, and BEL2014. First, the large-scale patterns in the region, in particular the SEP anticyclone, are relatively realistic under the climate of the last 50 years. ENSO processes are relatively well represented 


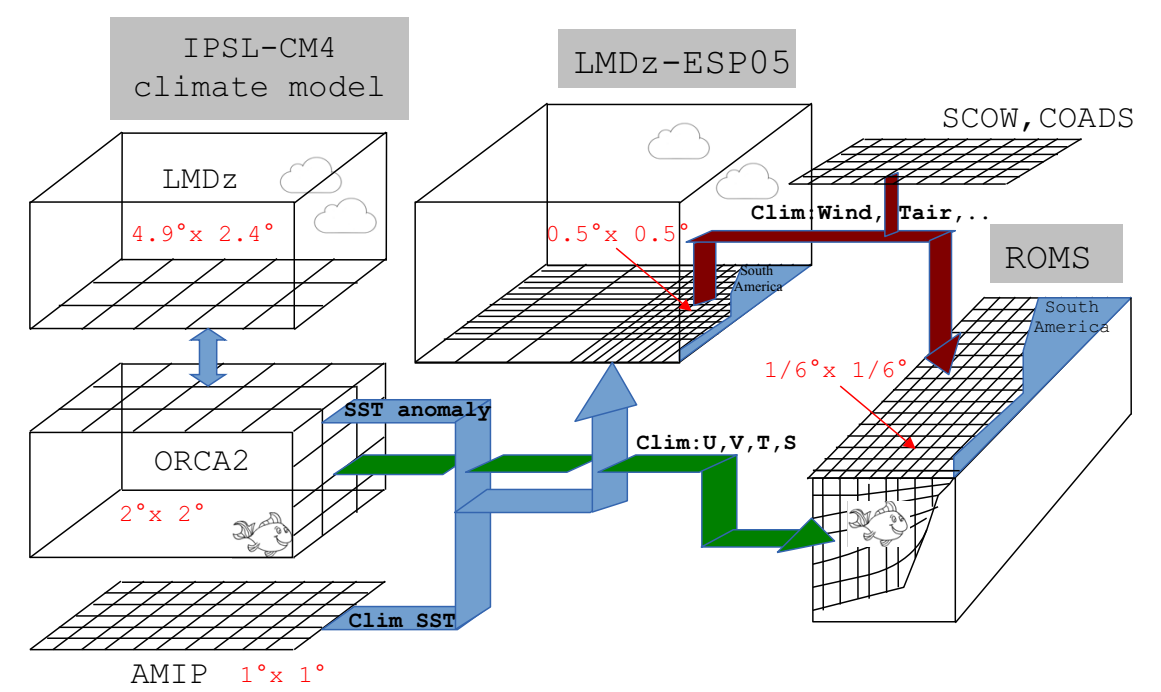

Figure 1. Schematic of the modeling methodology for $\mathrm{PI}, 2 \mathrm{CO} 2$ and $4 \mathrm{CO} 2$ scenarios. LMDz and ORCA2 are the atmospheric and oceanic component of the IPSL-CM4 CGCM. SST output from the large-scale IPSL-CM4 simulation is corrected in the following way: SST difference between the chosen scenario and 20C3M IPSL-CM4 simulations is added to AMIP observed SST. The climatology of this corrected SST field is used to force the high-resolution model LMDz-ESP05. Then, the same kind of correction is applied to the wind and heat flux from the atmospheric downscaling: differences between the chosen scenario and the LMDz-AMIP simulation are added to SCOW (for wind) or COADS (for heat fluxes). Finally, the climatology of these corrected fluxes is computed and used to force the ROMS ocean model. Initial and boundary conditions for the oceanic simulations come from the IPSL-CM4 model.

in IPSL-CM4 [Guilyardi, 2006]. Also, the SEP biological mean productivity simulated by IPSL-CM4 coupled with a biogeochemical model is quite realistic, in comparison with other global earth system models [Steinacher et al., 2010]. Last, when considering the modifications induced by global warming, the trends of SST, the SEP anticyclone poleward shift, and the alongshore wind changes in the upwelling region are close to those of the IPCC multimodel mean (GO2011, BEL2014).

Following GO2011 and EC2012, we use three idealized climate scenarios performed with the IPSL-CM4, corresponding to different $\mathrm{CO}_{2}$ atmospheric concentrations: preindustrial (PI) level in the $\mathrm{PI}$ scenario, and twice and four times the PI level in the 2CO2 and 4CO2 scenarios, respectively. We select the 1970-1999, 20502059, and 2120-2149 time periods for $\mathrm{Pl}, 2 \mathrm{CO} 2$, and 4CO2, respectively. We also use the 20th century climate simulation 20C3M from IPSL-CM4 (1990-2000) in a control experiment (see section 2.4).

\subsection{Observational Data Sets}

In this study, observations and reanalysis are used as forcing and also to evaluate the realism of our simulations. The Atmospheric Model Intercomparison Project (AMIP) SST data set [Hurrell et al., 2008] is a merged product based on the monthly-mean Hadley Centre SST data set version 1 and the National Oceanic and Atmospheric Administration weekly optimum interpolation SST analysis version 2. It covers the period from 1870 to 2012 with monthly data at $1^{\circ}$ resolution. The Quikscat scatterometer-derived SCOW climatology [Risien and Chelton, 2008] is a wind stress monthly climatology over the period 2000-2008 at $50 \mathrm{~km}$ resolution. COADS [DaSilva et al., 1994] is a monthly climatology of atmospheric heat fluxes over the period $1945-1989$ at $1^{\circ}$ resolution. Sea surface height (SSH) satellite data from AVISO are provided from 1992 to 2006 at $1 / 3^{\circ}$ resolution [Pascual et al., 2006]. The $9 \mathrm{~km}$ resolution Pathfinder satellite SST [Kilpatrick et al., 2001] cover the years 1982-2008. CARS is a merged monthly-mean climatology at $1 / 2^{\circ}$ resolution of oceanic observations over the last 50 years (www.cmar. csiro.au/cars). We also used Acoustic Doppler Current Profiler data, collected between 2008 and 2012 and analyzed by Chaigneau et al. [2013], to obtain a mean cross-shore vertical section of coastal alongshore currents between $7^{\circ} \mathrm{S}$ and $13^{\circ} \mathrm{S}$ from $30 \mathrm{~m}$ to $500 \mathrm{~m}$ depth and from 0 to $200 \mathrm{~km}$ offshore.

\subsection{The Dynamically Downscaled Atmospheric Forcing}

To obtain an atmospheric forcing at a relatively high spatial resolution, a dynamical downscaling method was designed by locally increasing the spatial resolution of the $\mathrm{LMDz}$ model. A refined grid is centered on the PCCS region (from $99^{\circ} \mathrm{W}$ to $61^{\circ} \mathrm{W}$ and from $36^{\circ} \mathrm{S}$ to $6^{\circ} \mathrm{N}$ ), where the horizontal resolution becomes progressively higher (from $4.9^{\circ} \times 2.4^{\circ}$ to $0.5^{\circ} \times 0.5^{\circ}$ in the Eastern South Pacific area). Details on this model 
Table 1. SST Forcing and Initial Conditions of the LMDz-ESP05 Simulations ${ }^{\mathrm{a}}$ Simulation Name LMDZ-AMIP LMDz-PI $\mathrm{LMDz}-2 \mathrm{CO} 2$ LMDz-4CO2

a LMDz-ESP05 is the atmospheric compound (LMDz) of the IPSL-CM4 CGCM, with a configuration using a refined horizontal grid $\left(1 / 2^{\circ}\right)$ near Peru and Chile. Initial conditions come from the IPSL-CM4 CGCM. The LMDz-ESP05 is forced by the climatological AMIP SST or a climatology of the IPSL-CM4 SST corrected with AMIP. 20C3M, PI, 2CO2, and 4CO2 correspond to IPSL-CM4 climate scenarios with atmospheric $\mathrm{CO}_{2}$ concentrations following, respectively, observed levels, fixed preindustrial levels, doubling, and quadrupling trends. set up, named LMDz-ESP05 hereafter, can be found in BEL2014. A slightly different version of the LMDz (e.g., with a higher vertical resolution in the marine boundary layer) has been used in the Peru-Chile region in a recent regional model intercomparison [Wyant et al., 2010], and comparison with observations showed that $\mathrm{LMDz}$ was quite realistic in terms of cloud cover, shortwave flux, and vertical profiles of humidity and temperature.

Several atmospheric simulations are performed with LMDz-ESP05. First, a control simulation forced with the AMIP climatological SST is performed to evaluate the LMDz-ESP05 model bias. We refer to this simulation as LMDz-AMIP. Then atmospheric simulations of IPSL-CM4 climate scenarios are performed. The IPSL-CM4 SST is interpolated on the LMDz-ESP05 horizontal grid to force this atmospheric model in the following way: to reduce the CGCM bias, AMIP SST, and the SST difference between the IPSL-CM4 chosen scenario and the IPSL-CM4 20C3M are added and a climatology is computed to construct a SST forcing field for the LMDz-ESP05 (see Figure 1, middle). Three simulations were performed: $\mathrm{LMDz}-\mathrm{PI}, \mathrm{LMDz}-2 \mathrm{CO} 2$, and $\mathrm{LMDz}-4 \mathrm{CO} 2$ corresponding to the PI, 2CO2, and 4CO2 scenarios, respectively. Each LMDz-ESP05 simulation is run for 10 years. LMDz-ESP05 simulations and their forcings are summarized in Table 1. As we focus on the seasonal cycle and annual mean changes, monthly climatologies from the LMDz-ESP05 surface outputs are computed and used to construct the ocean simulations forcing (see section 2.4).

\subsection{Regional Ocean Model}

The Regional Oceanic Modeling System (in its ROMS "AGRIF" version) [Shchepetkin and McWilliams, 2005, 2009] is used to simulate ocean dynamics. ROMS solves the primitive equations using the Boussinesq approximation and hydrostatic vertical momentum balance. It has a time-splitting, explicit free surface. Our domain extends from $40^{\circ} \mathrm{S}$ to $15^{\circ} \mathrm{N}$ and from $100^{\circ} \mathrm{W}$ to $70^{\circ} \mathrm{W}$, in a configuration at $1 / 6^{\circ}$ horizontal resolution and 32 vertical levels similar to that used in EC2012 and Cambon et al. [2013]. Bottom topography from ETOPO2 [Smith and Sandwell, 1997] is modified to accommodate to the IPSL-CM4 topography at the open boundaries. Air/sea fluxes are calculated online using atmospheric surface parameters (air temperature, wind speed, relative humidity, precipitation, radiative fluxes from LMDz-ESP05 and other data sets described below) and ROMS model SST as inputs for the bulk formulae [Liu et al., 1979].

To evaluate our atmospheric forcing methodology, we first performed three ROMS "control" simulations forced by the same initial/open boundary conditions from a climatology of the 20C3M simulation (all ROMS simulations are summarized in Table 2). The first one (named CR-SCOW) is forced by the SCOW wind stress climatology, and COADS heat fluxes [DaSilva et al., 1994]. It will be used as a reference. The second simulation (named CR-LMDz) was performed using climatological surface wind stress from LMDz-AMIP. In the third one (named CR-IPSL), climatological wind stress forcing from the coarse IPSL-CM4 model is used.

Although the surface winds from LMDz-AMIP are much more realistic than those of IPSL-CM4 (section 3.1), comparison between CR-SCOW and CR-LMDz (see section 3.2) shows that the use of downscaled winds to force ROMS still reproduces a substantial bias in the ocean circulation. Thus, in order to improve the realism of the oceanic solutions, we correct part of the atmospheric forcing bias prior to forcing the ocean circulation. Assuming that the bias in LMDz-ESP05 wind remains unchanged with global warming, we construct a new set of forcing by adding wind/flux differences between the LMDz-ESP05 scenarios (e.g., LMDz-PI, LMDz-2CO2, LMDz-4CO2) and LMDz-AMIP, and the SCOW/COADS observational monthly climatology in the following way: for a forcing field $\Phi$ and a given scenario $S=(P I, 4 C O 2,2 C O 2,20 C 3 M)$, the corrected field is $\Phi^{\prime}(\mathrm{S})=\Phi_{\mathrm{LMDZ}}(\mathrm{S})-\Phi_{\mathrm{LMDZ}}(20 \mathrm{C} 3 \mathrm{M})+\Phi_{\mathrm{obs}}$. Note that for the present climate scenario (20C3M), the corrected field is $\Phi^{\prime}=\Phi_{\mathrm{OBS}}$, so that the reference oceanic simulation for present conditions used in our climate scenarios comparison is CR-SCOW. The assumption is that using LMDz-ESP05 differences between a climate scenario and the 20C3M scenario eliminates the constant bias generated by the atmospheric model, following 
Table 2. Atmospheric (Wind Stress and Heat Fluxes) and Initial/Open Boundary Forcing of the ROMS Simulations ${ }^{\mathrm{a}}$

\begin{tabular}{llll} 
Simulation Name & \multicolumn{1}{c}{$\begin{array}{c}\text { Wind Stress } \\
\text { Forcing }\end{array}$} & \multicolumn{1}{c}{$\begin{array}{c}\text { Other Atmospheric } \\
\text { Forcing }\end{array}$} & $\begin{array}{c}\text { Initial and Boundary } \\
\text { Conditions }\end{array}$ \\
\hline CR-SCOW & SCOW & COADS & IPSL-CM4 20C3M \\
CR-LMDz & LMDz-AMIP & COADS & IPSL-CM4 20C3M \\
CR-IPSL & IPSL-CM4 20C3M & COADS & IPSL-CM4 20C3M \\
PI & SCOW & COADS & IPSL-CM4 PI \\
& + LMDz-PI & + LMDz-PI & \\
& - LMDz-AMIP & - LMDz-AMIP & \\
$2 \mathrm{CO} 2$ & SCOW & COADS & IPSL-CM4 2CO2 \\
& + LMDz-2CO2 & + LMDz-2CO2 & \\
& - LMDz-AMIP & - LMDz-AMIP & \\
$4 C O 2$ & SCOW & COADS & IPSL-CM4 4CO2 \\
& + LMDz 4CO2 & + LMDz-4CO2 & \\
& - LMDz-AMIP & - LMDz-AMIP & \\
$4 C O 2 a$ & SCOW & COADS & IPSL-CM4 PI \\
& + LMDz 4CO2 & + LMDz-4CO2 & \\
& - LMDz-AMIP & - LMDz-AMIP & \\
& &
\end{tabular}

${ }^{a} \mathrm{SCOW}$ are climatological wind observations. COADS is a climatology of short-wave and net heat fluxes. LMDz wind stress and heat fluxes are from the LMDz-ESP05 atmospheric model. For four simulations, wind stress and heat fluxes are decomposed into the sum of a climatological field (SCOW, COADS) and anomalies from the LMDz-ESP05. the same methodology as Bruyere et al. [2014]. Even though there is little alternative to our approach, it must be noticed that a bias in the mean state could result in a bias in the variance. The same method was used by EC2012 for heat fluxes.

Oceanic initial and boundary conditions for ROMS come from the ORCA2 model, the ocean component of the IPSLCM4 CGCM. Note that ORCA2 has a $2^{\circ}$ spatial resolution in the PCCS and an increased meridional resolution $\left(1^{\circ}\right)$ along the equator to better represent equatorial Kelvin waves [Marti et al., 2010]. For

each experiment, different initial and boundary conditions from IPSL-CM4 corresponding to the PI, 2CO2, and 4CO2 scenarios are used. The surface and open boundary conditions are monthly and climatological, and that these climatologies are computed over the time slots mentioned in section 2.1. An additional simulation, named 4CO2a, was performed using the PI atmospheric forcing and the 4CO2 oceanic boundaries, to investigate the impact of the atmospheric forcing change only. The characteristics of the atmospheric and oceanic forcing are summarized in Table 2. Each ROMS ocean simulation is run for 13 years and outputs are 5 day averages. As a statistical quasiequilibrium is reached after 3 years, we analyze monthly-means and annual-means of the 5 day averaged output over the last 10 years of the simulation.

\subsection{Lagrangian Analysis}

In order to study the origin of upwelled water masses, we use a ROMS-offline tracking module [e.g., Montes et al., 2010; Mason et al., 2012]. It is able to calculate neutrally buoyant floats trajectories from the stored 5 day averaged ROMS velocity field. Floats are tracked backward in time so that their trajectories previous to the release date are computed. Blanke and Raynaud [1997] showed that this kind of approach was valid to calculate the origin of water masses.

For each year of the last 10 years of simulation, 30,000 floats are released at the first day of each month with random locations between 0 and $50 \mathrm{~m}$ depth on the shelf (defined as the near shore region limited by the $200 \mathrm{~m}$ isobaths) between $7^{\circ} \mathrm{S}$ and $13^{\circ} \mathrm{S} .50 \mathrm{~m}$ corresponds to the maximum Ekman layer depth (see section 4.2.1) and also approximately defines the lower limit of the euphotic layer on the shelf [Guillen and Calienes, 1981]. Shallower depths were also tested and the results were unchanged. The trajectory of each float is integrated backward in time during 6 months. We examine the depth and latitude of the floats when they enter the shelf (i.e., when they cross the $200 \mathrm{~m}$ isobath). We also compute the time spent by the floats to travel from the shelf edge (i.e., $200 \mathrm{~m}$ isobath) to the upwelling area (called "shelf crossing time" in the following).

\section{Evaluation of the Simulation Realism}

\subsection{Atmospheric Simulations}

Annual means of the surface winds from the IPSL-CM4 20C3M scenario, the LMDz-AMIP, and SCOW are compared in Figure 2. Alongshore coastal wind is much more realistic in LMDz-AMIP than in IPSL-CM4. The Chilean coastal jet near $30^{\circ} \mathrm{S}$, virtually absent in IPSL-CM4, appears in LMDz-AMIP albeit slightly too broad (it extends from $32^{\circ} \mathrm{S}$ to $27^{\circ} \mathrm{S}$, instead of $30^{\circ} \mathrm{S}$ to $28^{\circ} \mathrm{S}$ ). Offshore $\mathrm{CP}$, the wind is slightly weaker: $6.5 \mathrm{~m} \mathrm{~s}^{-1}$ in the LMDz-AMIP instead of $7.5 \mathrm{~m} \mathrm{~s}^{-1}$ in the observations. The SEP anticyclone in LMDz-AMIP is also meridionally narrower by $1-2^{\circ}$ compared to the observations. 

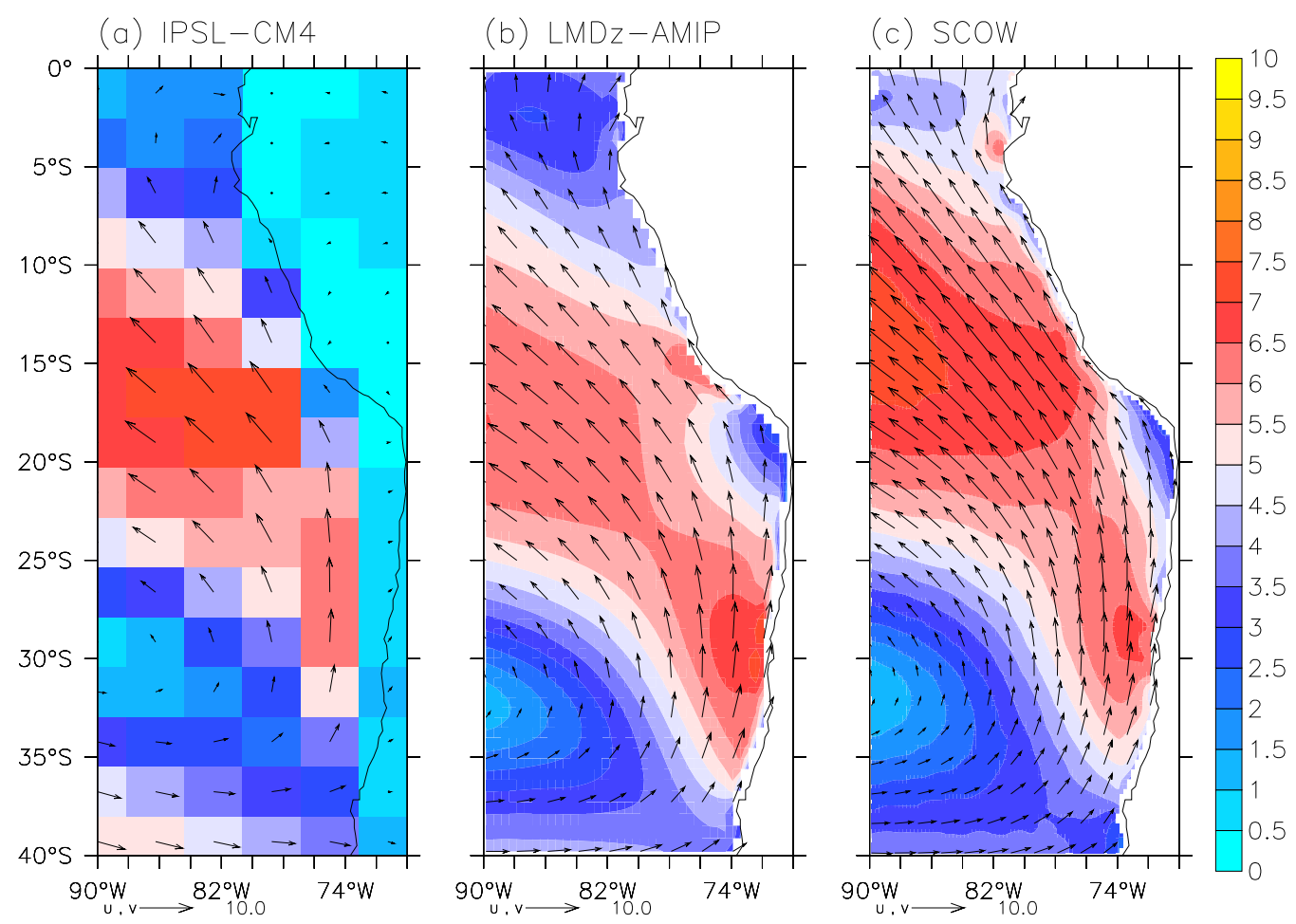

Figure 2. Annual-mean surface wind (in $\mathrm{m} \mathrm{s}^{-1}$ ) from (a) the coarse global coupled model IPSL-CM4, (b) the LMDz atmospheric model with a refined grid in the SEP, and (c) the SCOW climatology.

\subsection{Oceanic Simulations}

We first validate our methodology by evaluating the realism of the CR-SCOW ROMS simulation, which corresponds to the ocean circulation under present wind conditions. Results from the CR-LMDz solution are also presented to evaluate the bias introduced by the downscaled LMDz-AMIP forcing. Figure 3 compares the mean SST from CR-SCOW and Pathfinder observations. The coastal upwelling cold tongue is well
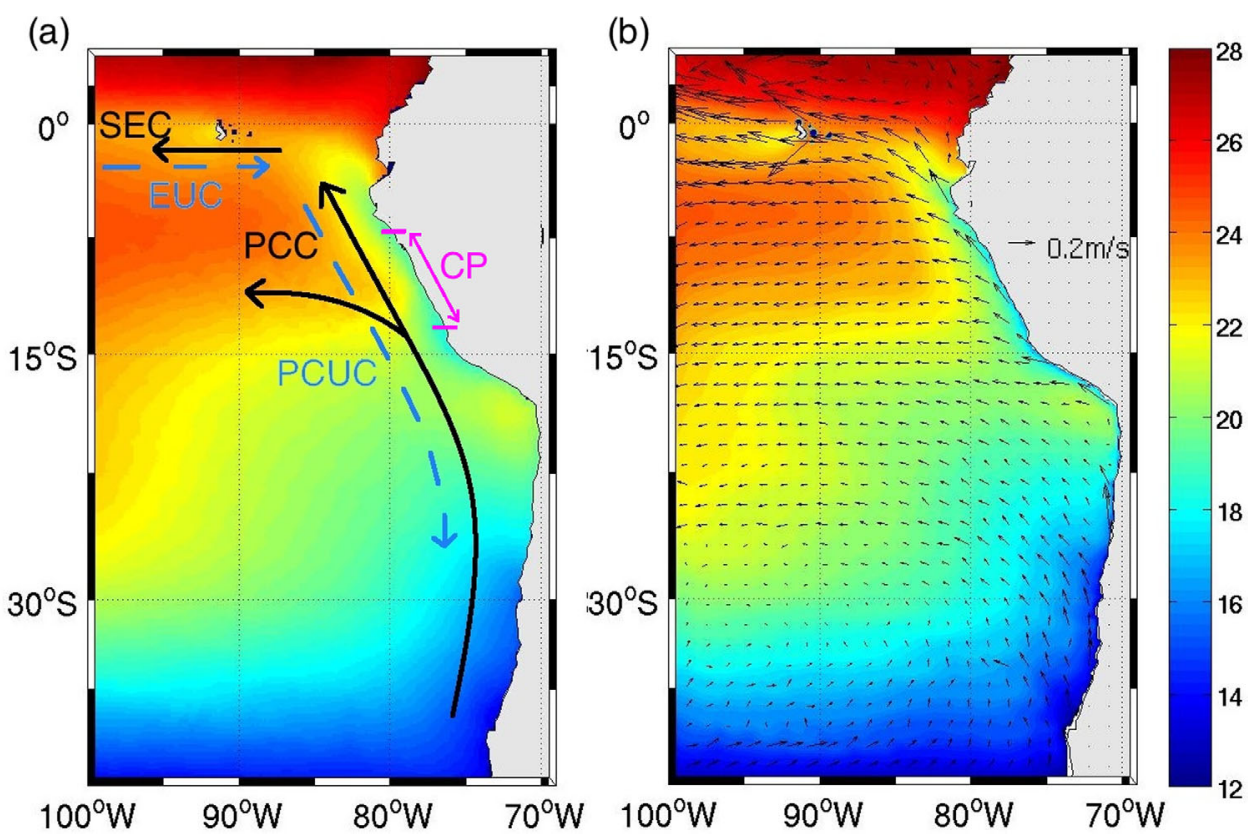

Figure 3. Annual mean SST (in ${ }^{\circ} \mathrm{C}$ ) for (a) Pathfinder observations and (b) the CR-SCOW simulation. Arrows in (a) represent the main currents in the PCCS (surface currents (South Equatorial Current, Peru Coastal Current) in black, and undercurrents in blue). Arrows in Figure 3b mark model mean surface velocities. The Central Peru (CP) region is indicated in magenta in Figure $3 a$. 

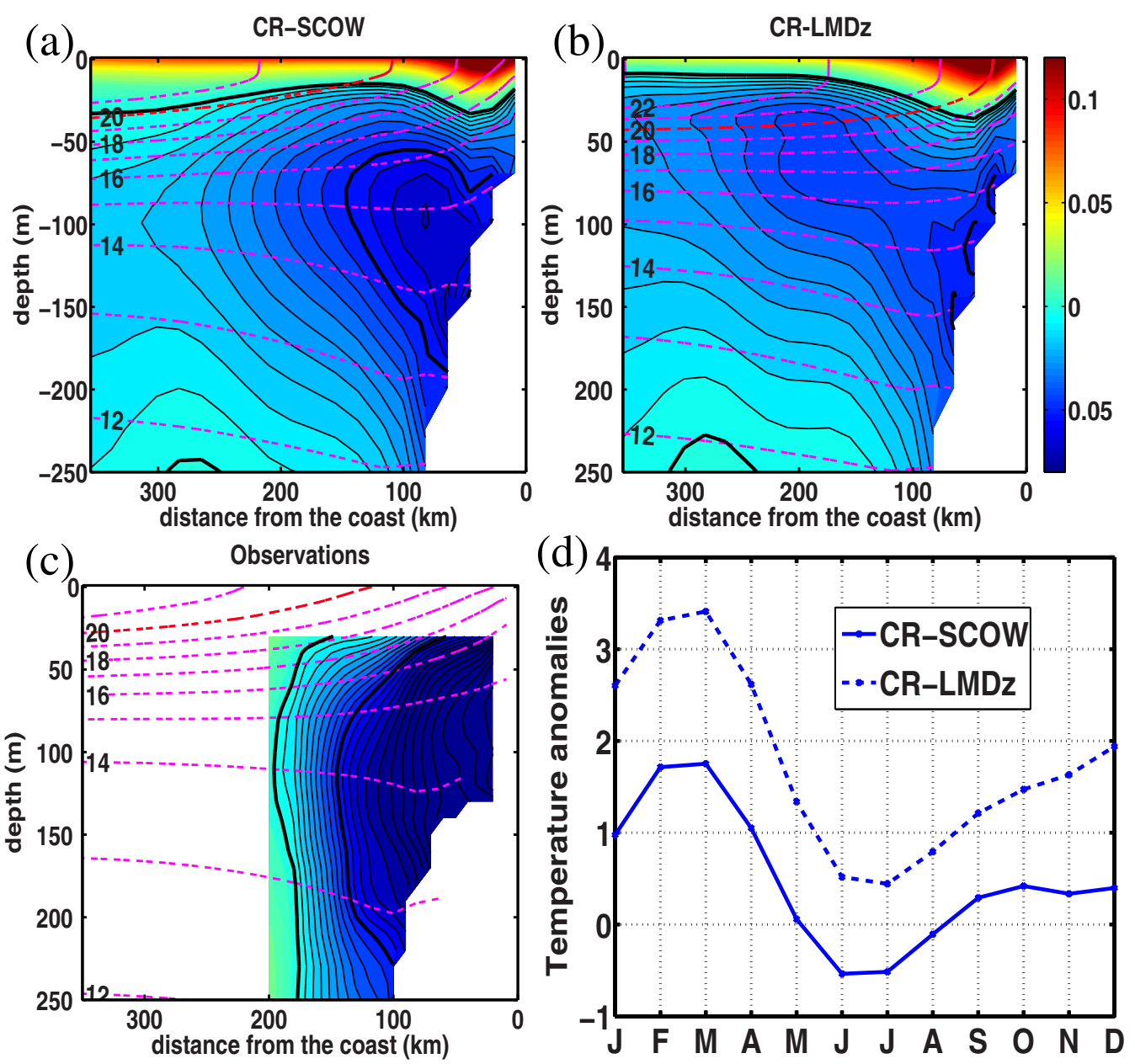

Figure 4. Annual mean alongshore velocities (shading, in $\mathrm{m} \mathrm{s}^{-1}$ ) and temperature (dashed magenta line, in ${ }^{\circ} \mathrm{C}$ ) averaged between $7^{\circ} \mathrm{S}$ and $13^{\circ} \mathrm{S}$ for (a) CR-SCOW, (b) CR-LMDz, and (c) observations. Thin black velocity contour interval is $0.5 \mathrm{~cm} \mathrm{~s}^{-1}$ and black bold contours marks 0 and $-5 \mathrm{~cm} \mathrm{~s}^{-1}$. Temperature contour interval is $1^{\circ} \mathrm{C}$ and red-dashed line marks the $20^{\circ} \mathrm{C}$ isotherm. Observed alongshore velocities cross-shore section in Figure 4c is adapted from Chaigneau et al. [2013]. They are only available between 0 and $200 \mathrm{~km}$ offshore and below $30 \mathrm{~m}$ depth. Temperature observations in Figure 4c are CARS data. (d) Annual cycle of temperature anomaly $\left({ }^{\circ} \mathrm{C}\right)$ with respect to the CARS climatology, averaged between $0 \mathrm{~m}$ and $100 \mathrm{~m}$ depth, $7^{\circ} \mathrm{S}$ and $13^{\circ} \mathrm{S}$ and from the coast to $360 \mathrm{~km}$ offshore.

reproduced by the model. SST differences with respect to Pathfinder are weak (less than $1^{\circ} \mathrm{C}$ ) in most of the model domain, except close to the Chilean coast $\left(\sim 1.5^{\circ} \mathrm{C}\right.$ cold bias). Model surface velocities display the coastal Peru-Chile current (PCC) flowing equatorward along the coast, and the south-equatorial current (SEC) flowing westward at the equator, among other currents. Surface fields from CR-LMDz (not shown) are close to CR-SCOW. The main subsurface currents in the region are also sketched on Figure 3a: the poleward PCUC and the equatorial undercurrent (EUC) flowing westward.

Figure 4 presents a mean cross-shore section of temperature and alongshore velocities for CR-SCOW, CRLMDz, and observations averaged between $7^{\circ} \mathrm{S}$ and $13^{\circ} \mathrm{S}$ [see Penven et al., 2005; Colas et al., 2012 for similar figures]. As the CP coast is almost straight, alongshore quantities between $7^{\circ} \mathrm{S}$ and $13^{\circ} \mathrm{S}$ were computed using a constant angle and are positive when flowing northward. Coastal upwelling is evidenced by isotherms tilting and reaching the surface near the coast. In the annual mean, differences in temperature with respect to the CARS climatology are less than $0.8^{\circ} \mathrm{C}$ for CR-SCOW. The PCC is $100 \mathrm{~km}$ wide and reaches a maximal depth of $\sim 30 \mathrm{~m}$. The core of the poleward PCUC located at $100 \mathrm{~m}$ depth reaches $6.5 \mathrm{~cm} \mathrm{~s}^{-1}$. Chaigneau et al. [2013] observations show that the PCUC is located in the first $200 \mathrm{~km}$ offshore with its core between 50 and $200 \mathrm{~m}$ depth (Figure 4c). CR-SCOW exhibits a similar PCUC structure; however, the simulated current is weaker.

In both CR-SCOW and CR-LMDz, the largest temperature bias with the CARS climatology is located in the upper $100 \mathrm{~m}$ of the water column (Figures $4 \mathrm{a}$ and $4 \mathrm{~b}$ ). The seasonal evolution of this temperature bias, 


\section{QAGU Journal of Geophysical Research: Oceans}
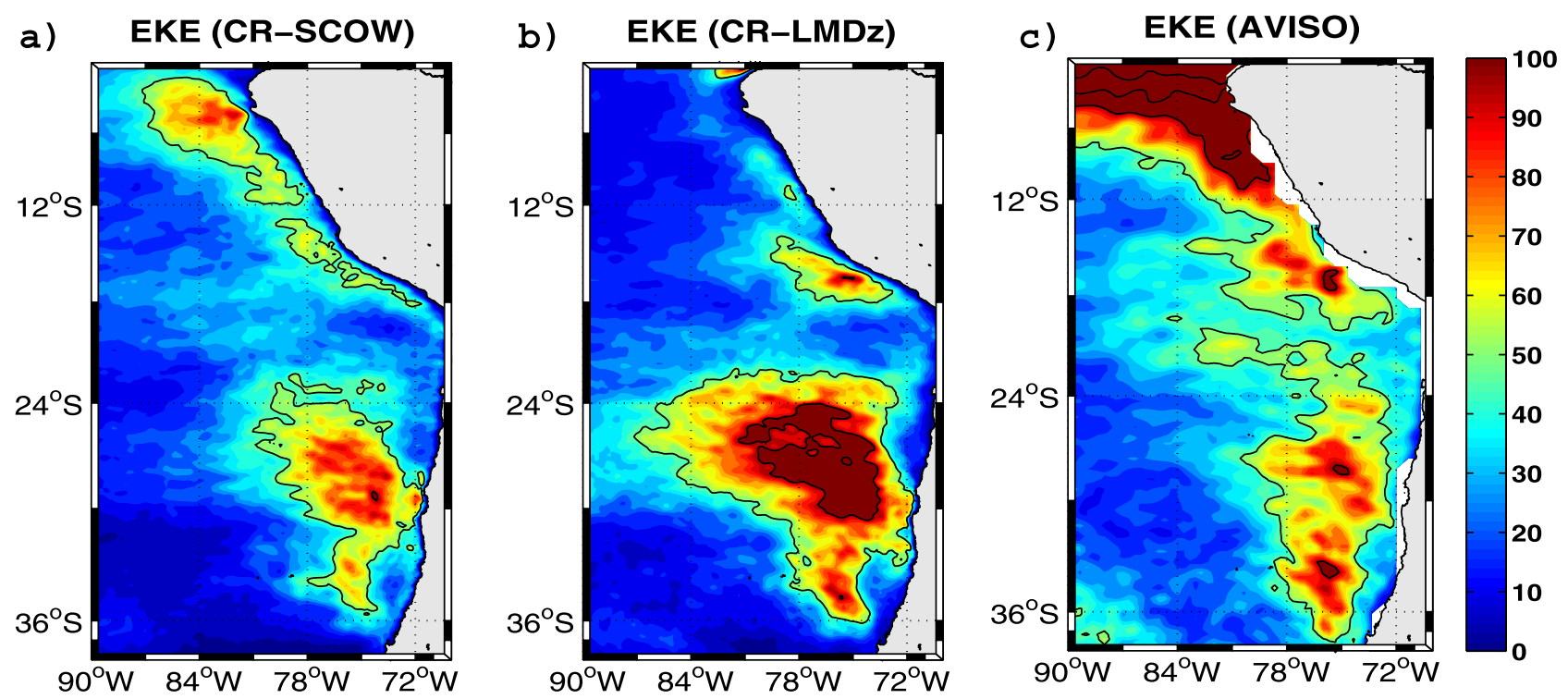

Figure 5. Annual mean eddy kinetic energy (EKE, in $\mathrm{cm}^{2} \mathrm{~s}^{-2}$ ) from (a) CR-SCOW, (b) CR-LMDz, and (c) AVISO observations. Contour interval is $50 \mathrm{~cm}^{2} \mathrm{~s}^{-2}$.

computed in the near-surface layer and averaged between $7^{\circ} \mathrm{S}$ and $13^{\circ} \mathrm{S}$, is shown in Figure $4 \mathrm{~d}$. The CRLMDz warm bias is more than twice as large as the CR-SCOW bias, due to a very reduced upwelling in CRLMDz. In addition, the coastal PCC in CR-LMDz extends further offshore (Figure 4b), reaching $150 \mathrm{~km}$ ( $\sim 100 \mathrm{~km}$ in CR-SCOW, Figure 4a). The structure of the PCUC is also strongly affected: its core is even less intense ( $\sim 5 \mathrm{~cm} \mathrm{~s}^{-1}$ in CR-LMDz versus $\sim 6.5 \mathrm{~cm} \mathrm{~s}^{-1}$ in CR-SCOW), extends further offshore and is shallower in CR-LMDz than in CR-SCOW. Appendix A presents a similar figure for CR-IPSL, forced by coarse IPSL winds, showing more unrealistic features.

Baroclinic instability due to the vertical shear between the PCC and PCUC alongshore velocities is an essential source of mesoscale eddy activity in this region (e.g., EC2012). Eddy kinetic energy (EKE) maps derived from CR-LMDz, CR-SCOW, and AVISO are represented in Figure 5. The observed maximum EKE alongshore strip north of $20^{\circ} \mathrm{S}$ is present in CR-SCOW, although weaker $\left(\sim 60 \mathrm{~cm}^{2} \mathrm{~s}^{-2}\right.$; Figure 5a) than in the observations ( $\sim 80-120 \mathrm{~cm}^{2} \mathrm{~s}^{-2}$; Figure $5 \mathrm{c}$ ). As the boundary conditions and wind forcing are climatological, part of the intraseasonal variability is not present in the model, which could partly explain the weaker modeled mesoscale eddy activity [e.g., Belmadani et al., 2012]. In the southern part of the domain, the high EKE patch off Chile is also present in CR-SCOW, and its amplitude agrees reasonably with the observed. In CR-LMDz, the EKE pattern is much closer to the observed (Figures $5 b$ and $5 c$ ) than in CR-IPSL (see Appendix A). However, some relatively strong biases remain such as an overly high EKE off Chile (Figure 5b) due to the LMDzAMIP wind forcing. In conclusion, the atmospheric downscaling improves the oceanic simulation but not enough to obtain realistic results. Therefore, we chose to modify the atmospheric forcing in the climate scenarios, in order to reduce this bias in the climate projections (see section 2.4).

\section{Results From the Climate Scenarios}

\subsection{Modifications of the Alongshore Circulation}

Figure 6 presents the annual wind stress forcing of PI, 2CO2, and 4CO2 from the corrected LMDz-ESP05 fields. Wind decrease in $2 \mathrm{CO} 2$ and $4 \mathrm{CO} 2$ compared to $\mathrm{PI}$ is clearly visible north of $30-35^{\circ} \mathrm{S}$, as described by BEL2014. The CP alongshore circulation forced by these scenarios is presented in Figure 7. The PCC gets shallower, with maximal depths of $35 \mathrm{~m}$ (PI), $30 \mathrm{~m}$ (2CO2), and $25 \mathrm{~m}$ (4CO2), whereas surface velocities increase from $\sim 12 \mathrm{~cm} \mathrm{~s}^{-1}$ (PI) to $\sim 24 \mathrm{~cm} \mathrm{~s}^{-1}$ (2CO2) and $\sim 21 \mathrm{~cm} \mathrm{~s}^{-1}$ (4CO2). The PCUC core intensifies from $6.5 \mathrm{~cm} \mathrm{~s}^{-1}$ (PI) to $7 \mathrm{~cm} \mathrm{~s}^{-1}$ (2CO2) and $7.5 \mathrm{~cm} \mathrm{~s}^{-1}$ (4CO2). Similar trends were also found by EC2012, but with a deeper PCC ( $\sim 70 \mathrm{~m}$ for PI and $\sim 40 \mathrm{~m}$ for 4CO2). EC2012 shows that whereas the PCUC seasonal 


\section{QAGU Journal of Geophysical Research: Oceans}
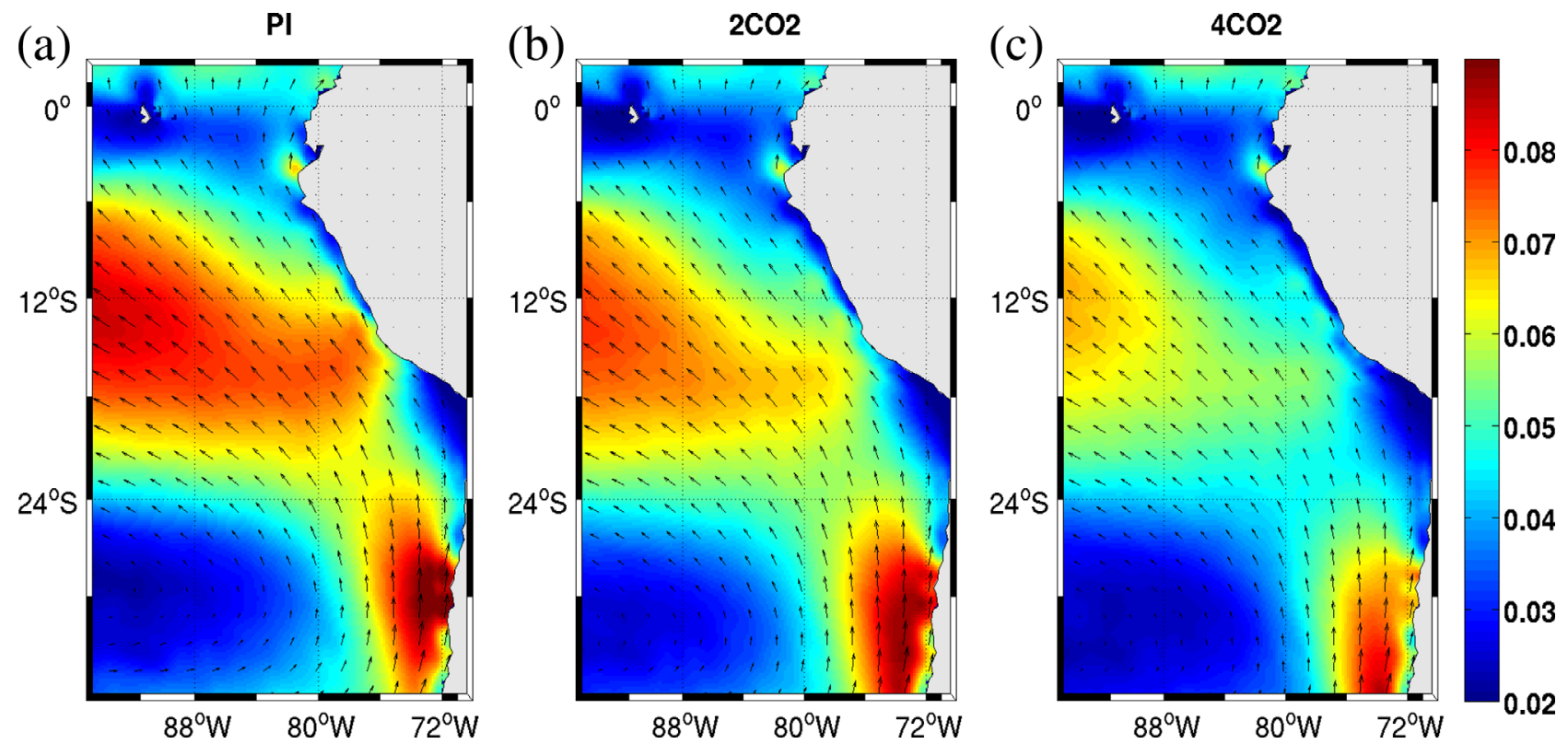

Figure 6. Annual mean wind stress for (a) $\mathrm{Pl}$, (b) 2CO2, and (c) 4CO2 simulations. Wind stress has been corrected by adding SCOW climatology and LMDz anomalies (see section 2.4).

cycle is correlated to the EUC imposed by the IPSL-CM4 oceanic boundary, the EUC mean transport exhibits no modifications between PI and 4CO2. The intensified 4CO2 PCUC is thus due to the wind forcing and the stratification changes. Note that Aiken et al. [2011] also found an increase in the PCUC and PCC intensities under a warming scenario (A2 SRES).

Eddy activity is also modified by the regional climate change. In the CP region, EKE is enhanced in $2 \mathrm{CO} 2$ and 4CO2 (Figure 8), which can be explained by the increased alongshore flow vertical shear. Off Chile, a high EKE pattern extends poleward in $2 \mathrm{CO} 2$ and 4CO2, which is consistent with the southward displacement of the SEP anticyclone and the poleward extension of the tropics. The EKE patterns resemble those presented by EC2012: both display a high EKE strip off Peru and another EKE maximum between $22^{\circ} \mathrm{S}$ and $36^{\circ} \mathrm{S}$ off Chile. However, substantial differences appear between EC2012 and our results. Following EC2012, we average the mean EKE in the three regional boxes represented in Figure 8, and the results are summarized in Table 3. EKE values are about half as intense as in EC2012. In both studies, the two climate-change scenarios (2CO2 and 4CO2) present higher EKE values than in the PI scenario, but without a clear trend: in our simulations, and unlike EC2012, the 2CO2 EKE is greater than the 4CO2 EKE in the three regions, which
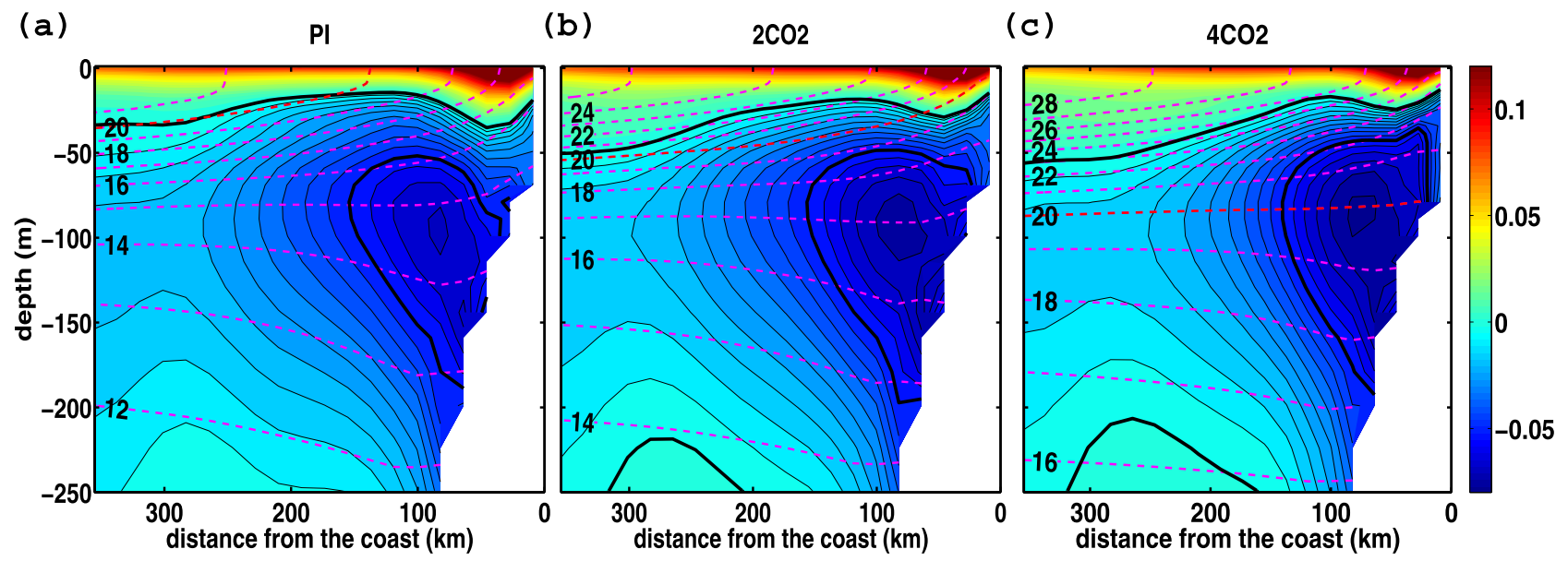

Figure 7. Same as Figure 4 but for the (a) $\mathrm{Pl}$, (b) 2CO2, and (c) $4 \mathrm{CO} 2$ simulations. 
a)

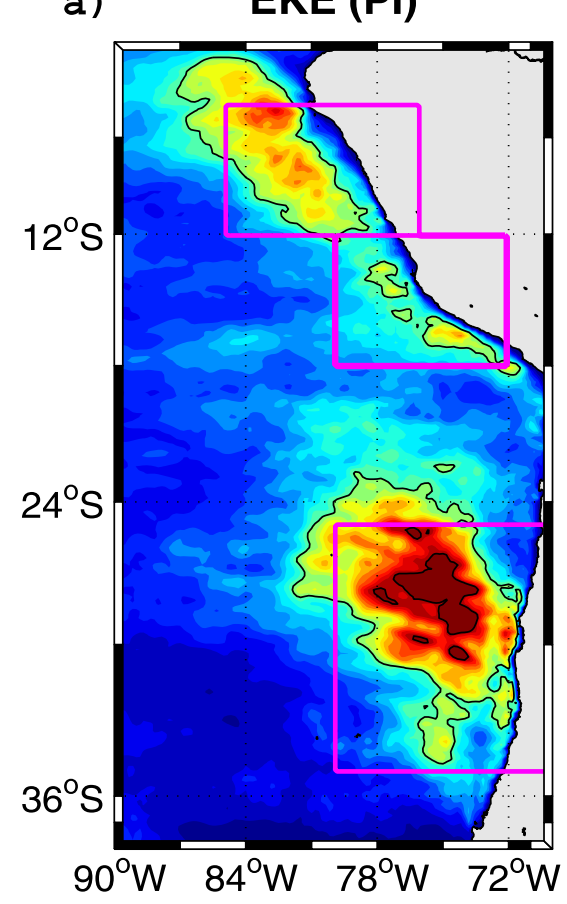

c)

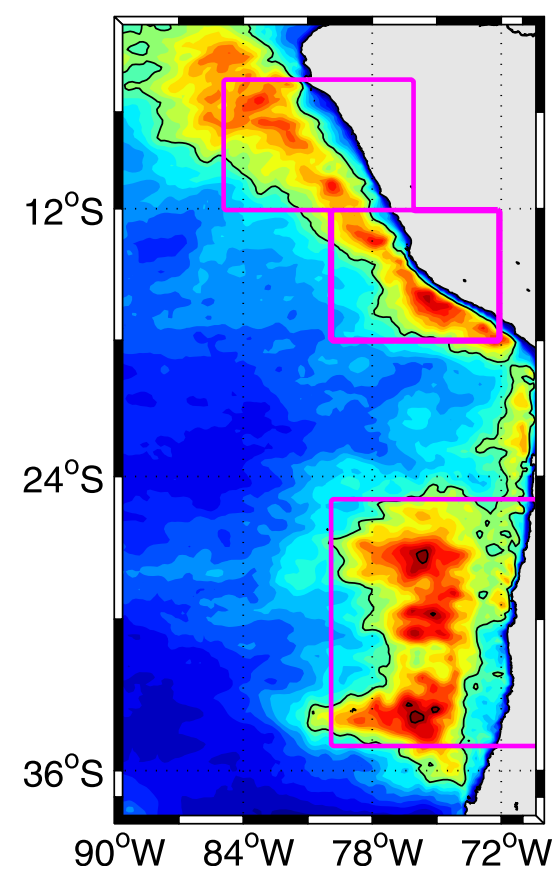

b) EKE (2CO2)

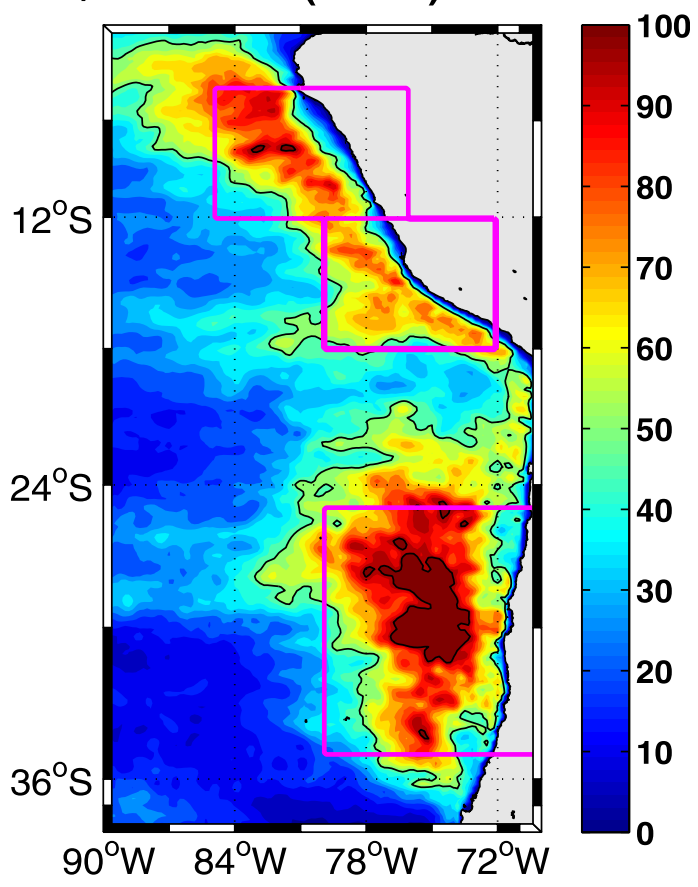

d)

EKE (4CO2a)

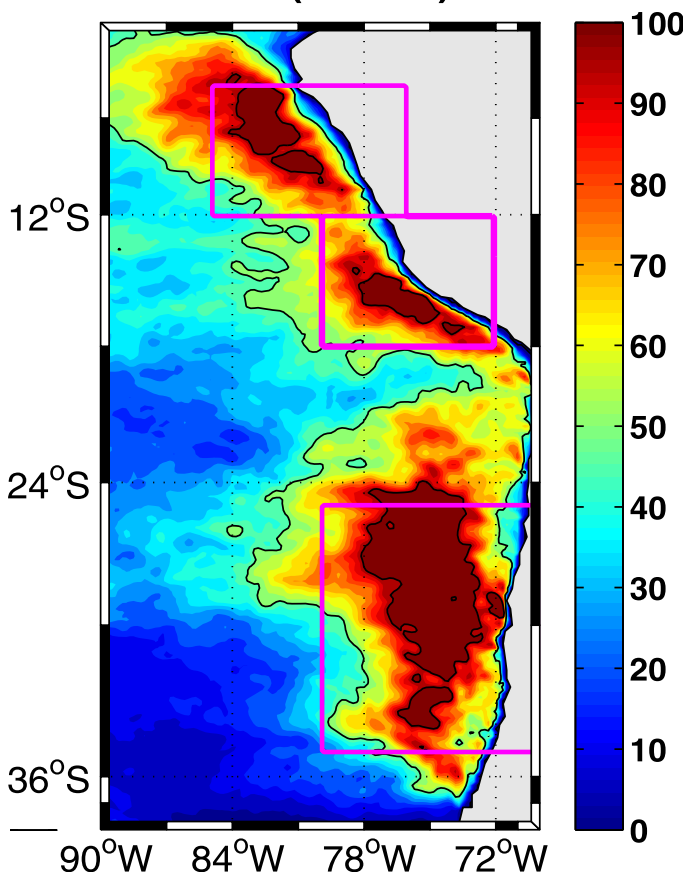

Figure 8. Same as Figure 5 but for the (a) $\mathrm{PI}$, (b) 2CO2, (c) 4CO2, and (d) $4 \mathrm{CO} 2 \mathrm{a}$ simulations. Boxes define the areas where mean EKE were calculated for Table 3.

may be due to an enhanced PCC, and current vertical shear, in 2 CO2 with respect to 4CO2. Besides, EC2012 found no clear EKE change off southern Peru $\left(\sim 12^{\circ} \mathrm{S}-18^{\circ} \mathrm{S}\right)$ whereas in our case, EKE intensifies along the entire Peru coast. Off Chile, the southward extension of the high EKE pattern in our 2CO2 and 4CO2 simulations (Figures 8b and 8c) is not reported in EC2012 which only presents an increase in the maximum value without any changes in the spatial pattern. To examine whether the EKE modifications are due to changes in the surface wind or in the ocean stratification, we analyze the 4CO2a simulation. 4CO2a (Figure 8d) and $\mathrm{PI}$ only differ by their oceanic open boundaries (4CO2 IPSL-CM4 and PI IPSL-CM4, respectively). It is clearly 
Table 3. EKE Average Values (in $\mathrm{cm}^{2} \mathrm{~s}^{-2}$ ) for 3 Nearshore Areas Off Northern Peru $\left(85^{\circ} \mathrm{W}-76^{\circ} \mathrm{W} ; 6^{\circ} \mathrm{S}-12^{\circ} \mathrm{S}\right)$; Southern Peru $\left(80^{\circ} \mathrm{W}-72^{\circ} \mathrm{W} ; 12^{\circ} \mathrm{S}-18^{\circ} \mathrm{S}\right)$; Central Chile $\left(80^{\circ} \mathrm{W}-70^{\circ} \mathrm{W} ; 25^{\circ} \mathrm{S}-35^{\circ} \mathrm{S}\right)^{a}$

\begin{tabular}{|c|c|c|c|c|c|c|}
\hline & $\mathrm{PI}$ & PI EC2012 & $2 \mathrm{CO} 2$ & 2CO2 EC2012 & $4 \mathrm{CO} 2$ & 4CO2 EC2012 \\
\hline EKE northern Peru & 51 & 114 & $\begin{array}{c}63 \\
(+23 \%)\end{array}$ & $\begin{array}{c}133.3 \\
(+17 \%)\end{array}$ & $\begin{array}{c}57 \\
(+12 \%)\end{array}$ & $\begin{array}{c}149 \\
(+30 \%)\end{array}$ \\
\hline EKE southern Peru & 40 & 97 & $\begin{array}{c}60 \\
(+50 \%)\end{array}$ & $\begin{array}{c}102 \\
(+5 \%)\end{array}$ & $\begin{array}{c}55 \\
(+38 \%)\end{array}$ & $\begin{array}{c}100 \\
(+3 \%)\end{array}$ \\
\hline EKE Central Chile & 57 & 98 & $\begin{array}{c}72 \\
(+26 \%)\end{array}$ & $\begin{array}{c}132 \\
(+35 \%)\end{array}$ & $\begin{array}{c}60 \\
(+5 \%)\end{array}$ & $\begin{array}{c}136 \\
(+38 \%)\end{array}$ \\
\hline
\end{tabular}

${ }^{a}$ EKE values are obtained under three climate change simulations ( $\mathrm{PI}, 2 \mathrm{CO} 2,4 \mathrm{CO} 2$ ) forced with dynamically (using LMDz model) and with statistically downscaled atmospheric forcing (see EC2012). Percentages are calculated with respect to the PI values.

seen that the 4CO2 IPSL-CM4 ocean boundary conditions account for the very large EKE increase. The 4CO2 wind decrease with respect to PI compensates this increase only partially. Note that Aiken et al. [2011] also noticed an enhanced EKE off Chile under global warming conditions.

\subsection{Upwelling Variations}

We now focus on coastal upwelling dynamics, which are particularly important for the productivity of the PCCS ecosystem. We first examine SST maps, as cross-shore SST gradients are illustrative of coastal upwelling intensity. Figure 9 presents the mean SST anomalies with respect to PI for the $2 \mathrm{CO} 2$ and $4 \mathrm{CO} 2$ scenarios. SST increases offshore by $\sim 2-3^{\circ} \mathrm{C}\left(\sim 4-6^{\circ} \mathrm{C}\right)$ in the $2 \mathrm{CO} 2(4 \mathrm{CO} 2)$, but the nearshore warming is even more intense, reaching $\sim 2.5^{\circ} \mathrm{C}\left(\sim 4^{\circ} \mathrm{C}\right)$ off Chile and $\sim 3.5^{\circ} \mathrm{C}\left(\sim 7^{\circ} \mathrm{C}\right)$ off Peru in the $2 \mathrm{CO} 2$ (4CO2). Different dynamical processes may cause an upwelling decrease: variations in Ekman current divergence at the coast due to alongshore equatorward wind stress, changes in the cross-shore geostrophic flow, and Ekman pumping modifications. In the following subsections, we analyze the role of these processes in detail.

\subsubsection{Cross-Shore Mass Balance}

We first study the seasonal evolution of cross-shore transport in a coastal band, which can be considered as a proxy of coastal upwelling, following Colas et al. [2008]. For each month, we calculate the mean horizontal
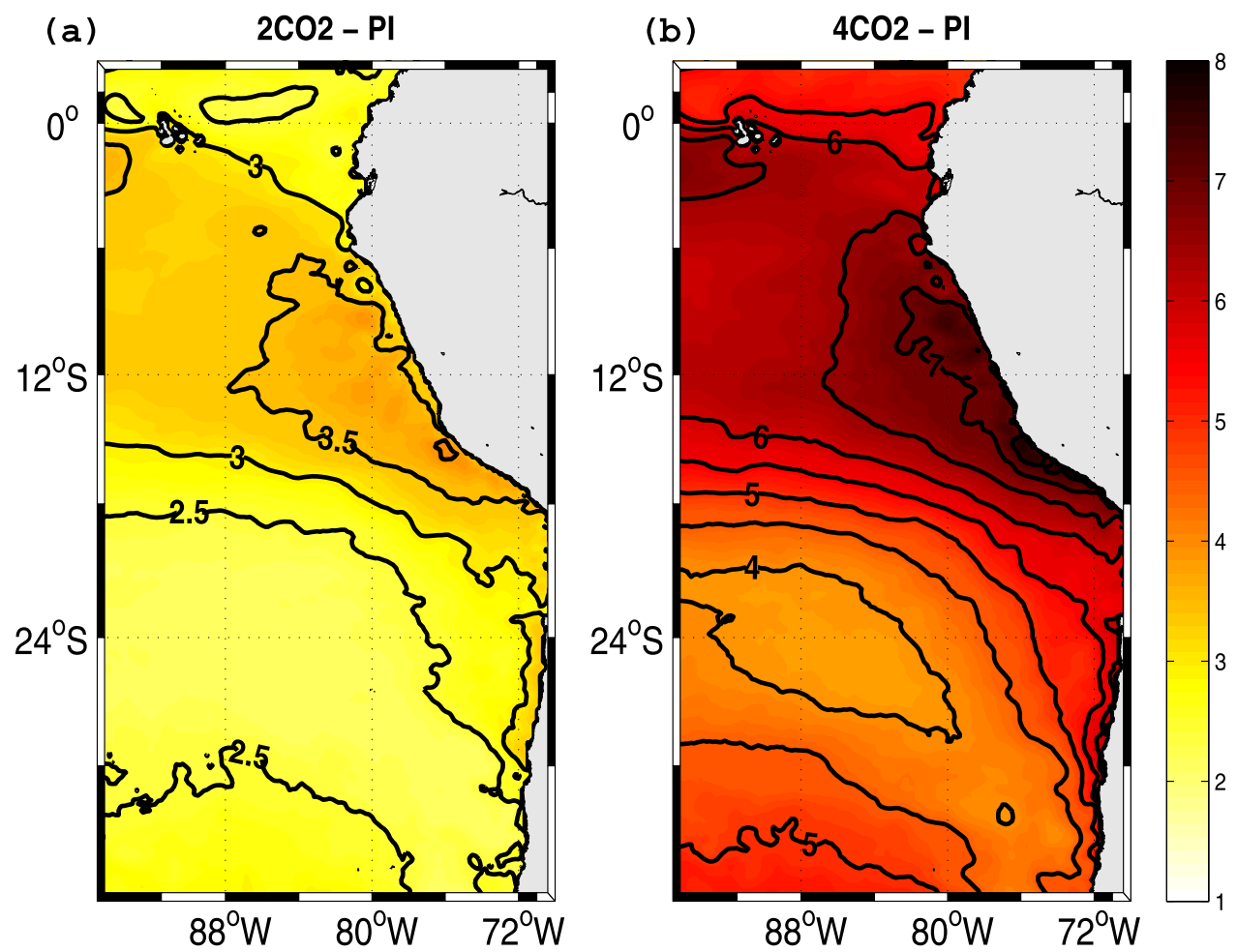

Figure 9. Annual mean sea surface temperature (SST, in ${ }^{\circ} \mathrm{C}$ ) anomalies with respect to $\mathrm{PI}$ for (a) $2 \mathrm{CO} 2$ and (b) $4 \mathrm{CO} 2$. The contour interval is $0.5^{\circ} \mathrm{C}$. 


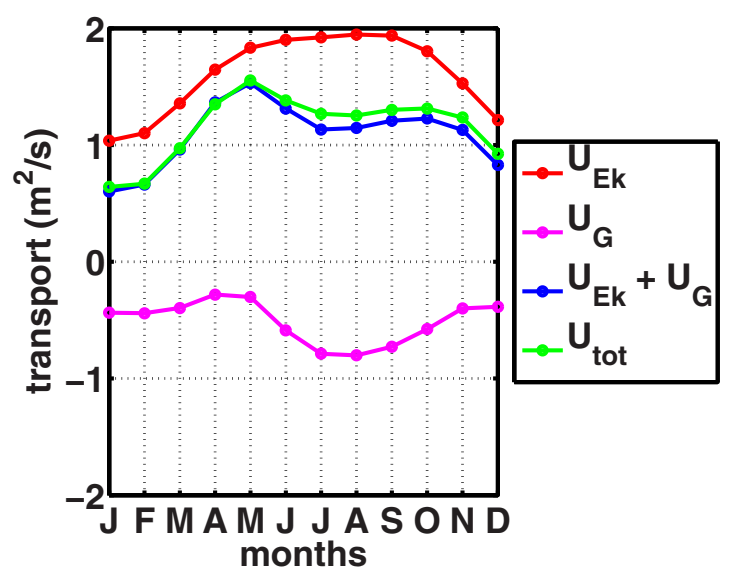

Figure 10. Seasonal cycle of the cross-shore transport (in $\mathrm{m}^{2} \mathrm{~s}^{-1}$ ) in the Ekman layer for CR-SCOW in a nearshore strip (from $7^{\circ} \mathrm{S}$ to $13^{\circ} \mathrm{S}$ and between 40 and $160 \mathrm{~km}$ offshore). Positive (negative) values are for seaward (shoreward) flow. $U_{E k}$ denotes the Ekman transport, $U_{G}$ the geostrophic transport, and $U_{\text {tot }}$ the total transport. transport in a coastal strip extending from $7^{\circ} \mathrm{S}$ to $13^{\circ} \mathrm{S}$ and from $40 \mathrm{~km}$ (two model grid points from the coast) to $160 \mathrm{~km}$ (eight model grid points from the coast) offshore. The Ekman transport $\mathrm{U}_{\mathrm{Ek}}$ is calculated with the mean alongshore stress $\tau_{\mathrm{a}}$ in the strip, following equation (1):

$$
U_{E k}=\frac{\tau_{a}}{\rho_{0} f}
$$

where $\rho_{0}$ is the water density and $f$ is the Coriolis parameter. $U_{E k}$ is compared with the crossshore transport $U_{\text {tot}}$, defined by the cross-shore velocity $u_{c}$ integrated vertically in the Ekman layer:

$$
U_{\text {tot }}=\int_{z_{e}}^{0} u_{c} d z
$$

To determine the Ekman layer depth $Z_{e}$, we assume that the flow in the Ekman layer is composed by the sum of the geostrophic and

Ekman currents. Following this assumption, the flow becomes entirely geostrophic below the Ekman layer. Thus, we compute the depth $\mathrm{Z}_{\mathrm{e}}$ below which the cross-shore total current $\mathrm{u}_{\mathrm{c}}$ equals the cross-shore geostrophic current $u_{c}^{G}$, within $10 \%$ of the surface value following (3):

$$
\frac{\left|u_{c}\left(z=Z_{e}\right)-u_{c}^{G}\left(z=Z_{e}\right)\right|}{\left|u_{c}(z=0)-u_{c}^{G}(z=0)\right|}<0.1
$$

The geostrophic current at a given depth is computed by the integration of the thermal wind relation from the surface to this depth, and the surface geostrophic velocity is derived from the model sea level slope. The comparison between the Ekman $\left(U_{E k}\right)$, total $\left(U_{\text {tot }}\right)$, and geostrophic transport $\left(\mathrm{U}_{\mathrm{G}}\right)$ is shown in Figure 10 for $\mathrm{CR}-\mathrm{SCOW}$. The mass balance is verified, as $\mathrm{U}_{\mathrm{tot}} \sim \mathrm{U}_{\mathrm{Ek}}+\mathrm{U}_{\mathrm{G}}$. Ekman transport overestimates total cross-shore transport by up to $40 \%$ in the annual means, due to a compensation by the shoreward geostrophic crossshore transport $\mathrm{U}_{\mathrm{G}}$ in the Ekman layer, as described by Colas et al. [2008] during El Niño events and by Marchesiello and Estrade [2010] in a more general context.

The same diagnostic is performed for the three climate scenarios and again the control run (Figure 11). The mass balance $\left(U_{\text {tot }} \sim U_{E k}+U_{G}\right)$ shown in Figure 10 is also valid in these cases (figures not shown). Ekman transport decreases under global warming conditions ( $-13 \%$ for $2 \mathrm{CO} 2$ and $-22 \%$ for $4 \mathrm{CO} 2$ with respect to PI, Figure 11a). Total cross-shore transport $\mathrm{U}_{\text {tot }}$ also decreases in the annual mean ( $-9 \%$ for $2 \mathrm{CO} 2$, and $-25 \%$ for $4 \times \mathrm{CO} 2$ with respect to $\mathrm{Pl}$, Figure $11 \mathrm{~b}$ ) and over the whole year except in late austral summer (February-April) when no significant change occurs. As in $\mathrm{CR}-\mathrm{SCOW}, \mathrm{U}_{\mathrm{G}}$ is shoreward all year long, but its compensation effect weakens from March to May in 2CO2 and 4CO2 (Figure 11c). Overall, the contributions of Ekman and shoreward geostrophic transports lead to a decrease in coastal upwelling except in March-April (Figure 11b).

To further investigate the change in geostrophic transport $\mathrm{U}_{\mathrm{G}}$ between $\mathrm{Pl}, 2 \mathrm{CO}$, and $4 \mathrm{CO} 2$, we approximated it by $u_{\text {surf }}^{G}=u_{c}^{G}(z=0) * Z_{e}$, thus neglecting geostrophic velocity vertical shear in the Ekman layer. The alongshore wind stress decrease (see Figure 11a and BEL2014) and enhanced thermal stratification in 4CO2 (see section 4.2 .3 ) result in a $\sim 30 \%$ decrease in $Z_{e}$ all year round (Figure 12 ). On the other hand, the annual mean surface geostrophic velocity (derived from the sea surface height (SSH) difference at $13^{\circ} \mathrm{S}$ and $7^{\circ} \mathrm{S}$, averaged from 40 to $160 \mathrm{~km}$ offshore) varies little between $\mathrm{PI}$ and $4 \mathrm{CO} 2\left(\sim 1.8 \mathrm{~cm} \mathrm{~s}^{-1}\right.$ in both scenarios, figure not shown). Thus, the annual mean decrease in geostrophic transport (Figure 11c) is mainly due to the Ekman layer shoaling caused by the stratification increase (Figure 12) rather than a change in mean surface geostrophic velocity. However, the amplitude of the seasonal variations of $u_{c}^{G}(z=0)$ increases in $4 \mathrm{CO} 2$ with respect to $\mathrm{PI}$ (figure not shown), leading to a similar increase in the seasonal cycle of $\mathrm{U}_{\mathrm{G}}$. Such variations are related to the poleward propagation of coastally trapped waves forced by equatorial Kelvin waves (EKW) reaching the coast of Ecuador [e.g., Pizarro et al., 2001; Echevin et al., 2011; Belmadani et al., 2012]. EKW are 


\section{QAGU Journal of Geophysical Research: Oceans}

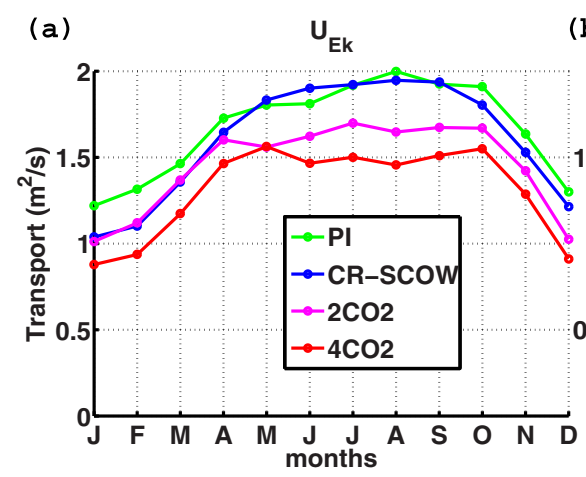

(b)

$\mathbf{U}_{\text {tot }}$

c)
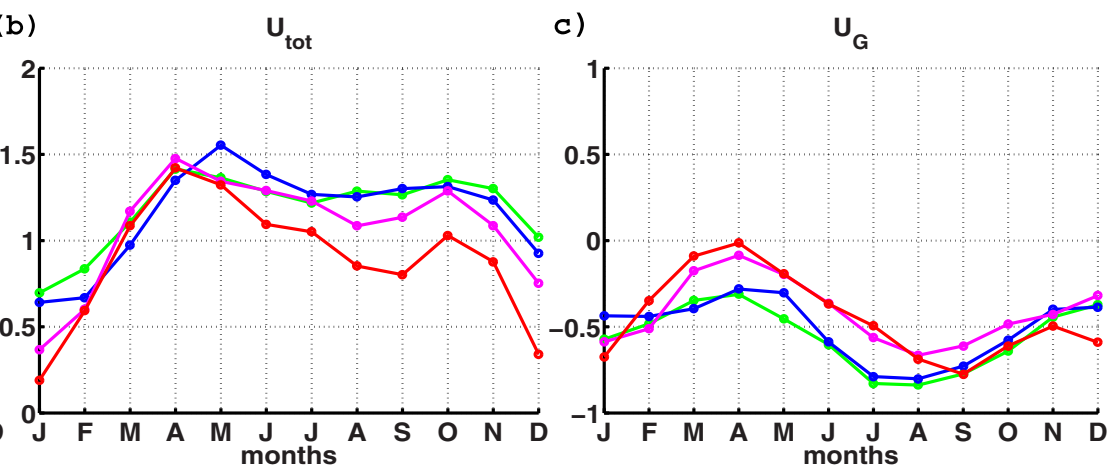

Figure 11. Seasonal cycle of the cross-shore transport terms (in $\mathrm{m}^{2} \mathrm{~s}^{-1}$ ) in the Ekman layer in the same strip as in Figure 10: (a) Ekman transport, (b) total cross-shore transport, and (c) geostrophic cross-shore transport. The different climate scenarios (PI, CR-SCOW, 2CO2, and 4CO2, respectively) are marked by different colors (green, blue, pink, and red, respectively).

represented in the IPSL-CM4 solutions, and the seasonal cycle of SSH resulting from their propagation is fairly realistic in the $20 \mathrm{C} 3 \mathrm{M}$ simulation (figures not shown). Thus, the western boundary conditions imposed at the equator force the eastward propagation of seasonal waves along the equator and along the Peruvian coast in the ROMS model. We represent SSH anomalies at the northern $\left(7^{\circ} \mathrm{S}\right)$ and southern $\left(13^{\circ} \mathrm{S}\right)$ extremities of the CP shelf (averaged from 40 to $160 \mathrm{~km}$ offshore) in Figure 13. The coastal signal is correlated with the equatorial signal in the two scenarios (correlations of 0.83 and 0.85 for PI and 4CO2, respectively) with a time lag of $\sim 1$ month as a result of eastward and poleward propagation. Bottom friction has a dissipative effect on the coastal-trapped waves [Brink, 1982], which may explain the poleward decrease $(\sim 20 \%$ between $7^{\circ} \mathrm{S}$ and $13^{\circ} \mathrm{S}$ in both scenarios) in coastal SSH variability. As sea level seasonal variations are enhanced in the $4 \mathrm{CO} 2$ scenario, this leads to an increase in the variations of the sea level slope between $7^{\circ} \mathrm{S}$ and $13^{\circ} \mathrm{S}$, and, thus, of $u_{c}^{G}(z=0)$.

\subsubsection{Ekman Pumping}

We now investigate upwelling in the offshore transition zone where negative wind stress curl generates upward Ekman pumping, which could have an important impact on the ecosystem [e.g., Rykaczewski and Checkley, 2008].

Vertical velocity decomposition in geostrophic and Ekman terms leads to Equation (4) (see section 1.3 in Pedloski [1996]):

$$
W_{\text {tot }}=w\left(z=Z_{e}\right)=\operatorname{curl}\left(\frac{\tau}{\rho_{0} f}\right)-\int_{z_{e}}^{0} \frac{\beta}{f} v_{G} d z=W_{E k}+W_{G}
$$

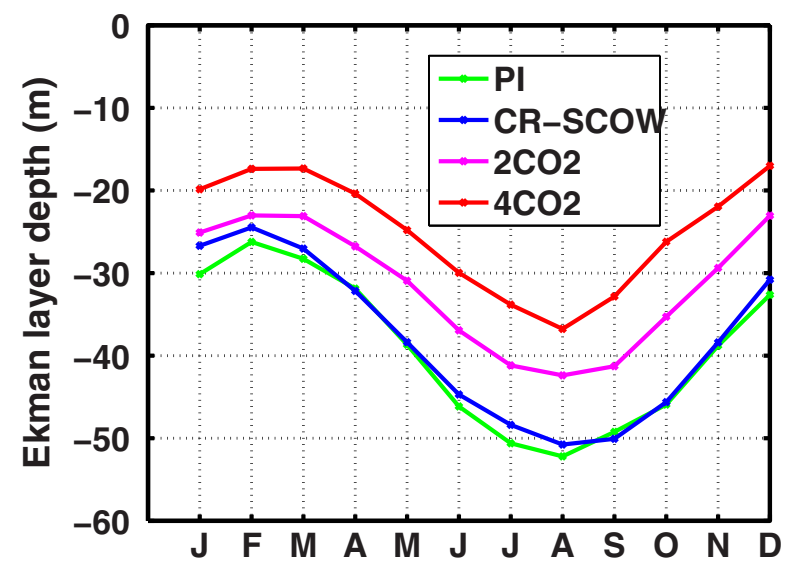

Figure 12. Seasonal cycle of the Ekman layer depth (in meters) averaged in the coastal strip (from $7^{\circ} \mathrm{S}$ to $13^{\circ} \mathrm{S}$ and from 40 to $160 \mathrm{~km}$ offshore) for the $\mathrm{PI}$, CR-SCOW, 2CO2, and the 4CO2 simulations.
With $\mathrm{W}_{\text {tot }}$ the vertical velocity at the base of the Ekman layer, $w$ the vertical velocity, $\tau$ the surface wind stress, $\beta$ the meridional gradient of the Coriolis parameter, and $\mathrm{v}_{\mathrm{G}}$ the meridional geostrophic velocity. Generally, the geostrophic vertical velocity $\mathrm{W}_{\mathrm{G}}$ is neglected so that vertical velocity is assumed to be solely driven by the Ekman pumping $W_{\text {ek. }}$. We evaluate the different terms ( $W_{\text {tot, }}, W_{E k}$, and $\left.W_{G}\right)$ of equation (4) in a strip off Peru, extending from $7^{\circ} \mathrm{S}$ to $13^{\circ} \mathrm{S}$ and from 40 to $160 \mathrm{~km}$ offshore, which corresponds to the coastal transition zone. At each grid point of the strip, we compute the different terms at the Ekman layer depth $Z_{e}$ (defined in subsection 4.2.1), and average them over the whole strip. 


\section{QAGU Journal of Geophysical Research: Oceans}
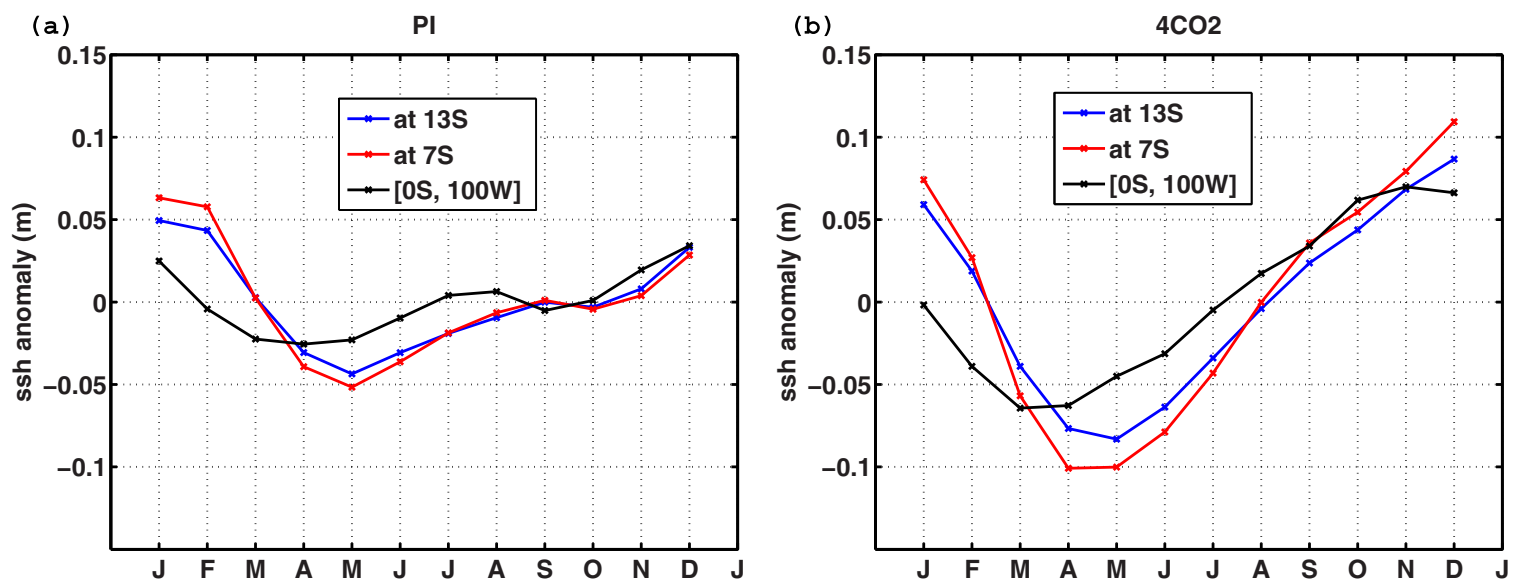

Figure 13. Seasonal cycle of the nearshore sea surface height (SSH, in meters) anomaly in three different locations: averaged from 40 to $160 \mathrm{~km}$ offshore at $7^{\circ} \mathrm{S}$ and $13^{\circ} \mathrm{S}$ and on the Equator at the western boundary of the model $\left(100^{\circ} \mathrm{W}\right)$ for the (a) $\mathrm{PI}$ and (b) $4 \mathrm{CO} 2$ simulations.

Ekman pumping decreases in the annual mean ( $-3 \%$ for $2 \mathrm{CO} 2$ and $-16 \%$ for $4 \mathrm{CO} 2$ ) with respect to $\mathrm{PI}$, and is lower in $2 \mathrm{CO} 2$ and $4 \mathrm{CO} 2$ than in PI for all seasons (Figure 14a). In contrast, $\mathrm{W}_{\text {tot }}$ is slightly larger in $2 \mathrm{CO} 2$ and 4CO2 than in PI from March to June (Figure 14b). It is thus important to note that $\mathrm{W}_{\mathrm{Ek}}$ alone does not fully explain all the variations in $\mathrm{W}_{\text {tot, }}$, but rather underestimates $\mathrm{W}_{\text {tot }}$ by up to $30 \%$ in our case. Taking $\mathrm{W}_{\mathrm{G}}$ into account (Figure $14 \mathrm{c}$ ) reduces the error by $\sim 50 \%$. Note that the small differences $(\sim 7-13 \%)$ between $\mathrm{W}_{\text {tot }}$ (Figure 14b) and $\left(\mathrm{W}_{\mathrm{Ek}}+\mathrm{W}_{\mathrm{G}}\right)$ (Figure 14c) could be attributed to ageostrophic motion taking place at the base of the surface layer.

\subsubsection{Source of Upwelled Water}

An important upwelling characteristic is the depth of the source water, i.e., the offshore depth of the water parcels before they are upwelled near the coast. A change in source water depth may affect their nutrient content and the nearshore productivity [e.g., Rykaczewski and Dunne, 2010; Albert et al., 2010]. Here we study the modifications in the source water origin (depth and latitude range) with the methodology described in section 2.5. Results are presented for the PI and 4CO2 simulations only (2CO2 provides results similar to 4CO2). For a given month, source water depths and latitude from distinct simulation years present approximately the same mean and standard deviation (figures not shown), since our simulations forced by climatological boundary and atmospheric forcings present a weak interannual variability. Therefore, we present climatological results, i.e., averaged for each month over 10 years.

Figure 15a presents the shelf crossing time as a function of particle release date. There are no striking differences between the two climate scenarios : source water parcels need, on average, $\sim 2$ months to cross the
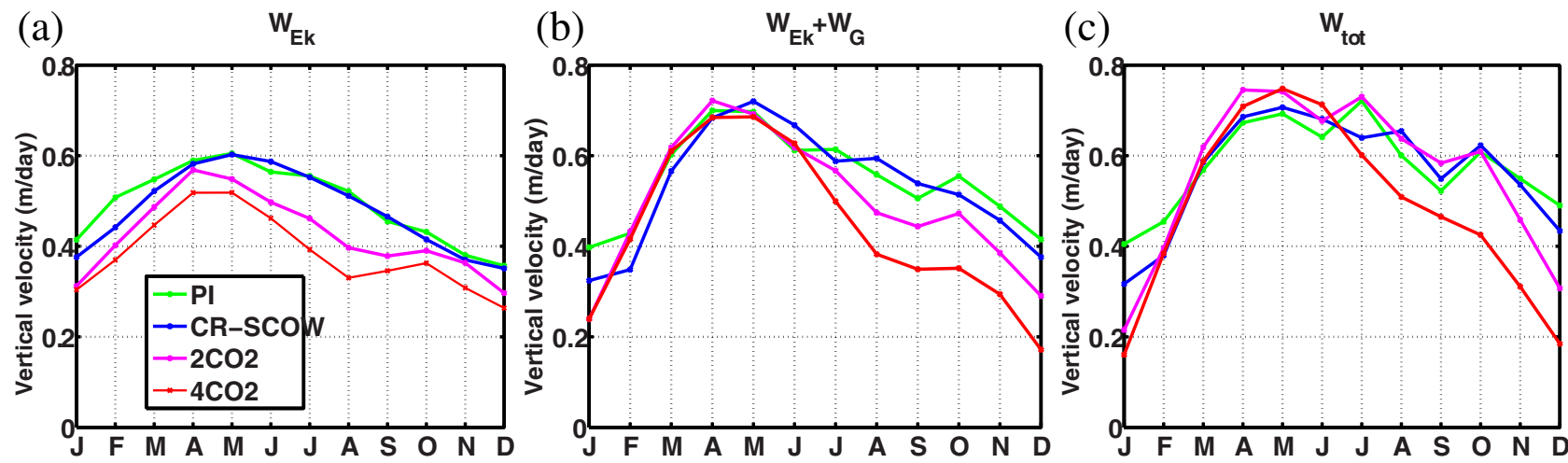

Figure 14. Seasonal cycle of (a) the Ekman pumping $\left(\mathrm{W}_{\text {ek, }}\right.$ in $\left.\mathrm{m} \mathrm{d}^{-1}\right)$, (b) the vertical velocity at the base of the Ekman layer ( $\left.\mathrm{W}_{\text {tot }}\right)$, (c) the sum of the Ekman pumping and geostrophic vertical velocity $\left(\mathrm{W}_{\mathrm{ek}}+\mathrm{W}_{\mathrm{G}}\right)$, averaged over an offshore strip $\left(7^{\circ} \mathrm{S}-13^{\circ} \mathrm{S}, 40-160 \mathrm{~km}\right.$ from shore). The different climate scenarios (PI, CR-SCOW, 2CO2, and $4 \mathrm{CO} 2$, respectively) are marked by different colors (green, blue, pink, and red, respectively). 


\section{CAGU Journal of Geophysical Research: Oceans}

(a)

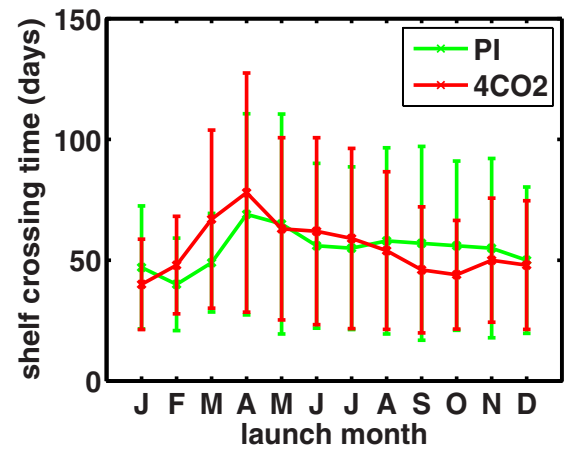

(b)

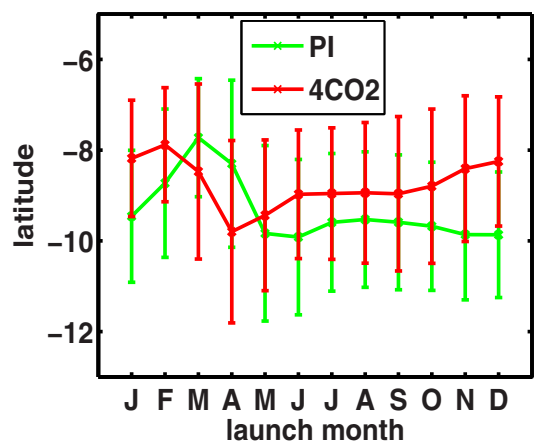

(c)

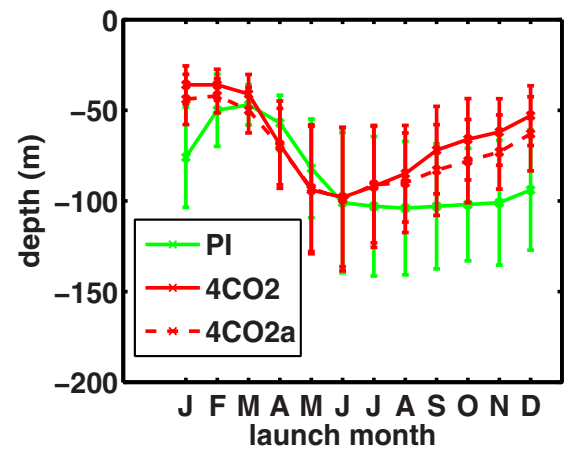

Figure 15. Seasonal variations of the source water characteristics: (a) shelf crossing time (in days), (b) latitude (in degrees), and (c) depth (in meters), of the source water parcels for the $\mathrm{PI}$ (green) and 4CO2 (red) simulations. Time evolution is shown as a function of release date. Vertical bars represent standard deviation from the average over all the floats.

shelf and reach the surface layer. Standard deviation is large: in some cases (e.g., the floats reaching the upwelling zone in April), some floats take less than a month to cross the shelf whereas others take up to 4 months. This can be partly explained by the different initial depths of the particles. When entering the shelf, deep particles are advected by a slow cross-shore current (less than $1 \mathrm{~cm} \mathrm{~s}^{-1}$ below $80 \mathrm{~m}$ depth, figure not shown) while particles in the upper part of the onshore flow are advected by a faster current $\left(\sim 1-2 \mathrm{~cm} \mathrm{~s}^{-1}\right.$ between 50 and $80 \mathrm{~m}$, figure not shown). Furthermore, deep particles also need more time than shallow ones to reach the surface layer due to slower vertical velocities ( $<1 \mathrm{~m} \mathrm{~d}^{-1}$, figure not shown).

Figure $15 \mathrm{~b}$ presents the changes in source water latitude. While the source water enters the shelf further north, with the exception of late austral summer (February-April). Rivas and Samelson [2010] performed a similar modeling experiment of the Oregon upwelling zone to track the source waters reaching a crossshore coastal section. They showed, rather expectedly, that the latitude of the source water is located north of the section when the floats are released in the southward surface current, and south of the section when their launching depth was located in the northward countercurrent (see their Figures 9a and 9c). In our study, particles are either advected equatorward in the PCC or poleward in the PCUC prior to being upwelled. As the PCC is shallower in the 4CO2 simulation (see section 3.2 and Figure 7c), fewer (more) floats are initially released in the equatorward (poleward) flow, which results in a mean latitude of source water parcels located further north in 4CO2 than in $\mathrm{PI}$. In addition, the PCUC being more intense in 4CO2 than in $\mathrm{PI}$, a water parcel advected for a same duration ( 2 months, Figure 15a) in the PCUC will cover a larger distance in 4CO2 than in PI. This also leads to an entrance on the shelf located further north in the 4CO2 case.

The seasonal variations of source water depth are represented in Figure 15c. Particle depths are much shallower in the 4CO2 scenario (differences between both simulation reaches $\sim 50 \mathrm{~m}$ in austral spring) except in April-May. Lentz and Chapman [2004] showed that the cross-shore isopycnal slope in a coastal upwelling system is proportional to $\frac{f}{N^{\prime}}$ with $N$ the Brunt-Väisälä frequency. Thus, in the case of an unchanged wind forcing and a stratification increase, isopycnal slope reduces, and the deeper layers do not reach the surface near the coast [Roemmich and McGowan, 1995]. Hence, an enhanced stratification leads to a shallower source of upwelled water. Figure 16a presents a mean cross-shore section of the stratification difference between $\mathrm{PI}$ and 4CO2 and the respective positions of the mean pycnocline (note that pycnocline and thermocline depths are almost identical). As expected, 4CO2 is more stratified than $\mathrm{PI}$ and its pycnocline is slightly shallower. The shelf-averaged $\int N^{2} . d z$ (averaged over the area comprised between $7^{\circ} \mathrm{S}, 13^{\circ} \mathrm{S}$, the coast, and the $200 \mathrm{~m}$ isobath and depth-integrated from the surface to $150 \mathrm{~m}$ depth) shows a larger stratification all year round in 4CO2 with respect to PI (Figure 16b). Changes of the coastal wind stress structure can also modify the upwelling sources [e.g., Song et al., 2011]. Nearshore stratification in 4CO2a is very close to $4 \mathrm{CO} 2$ because it is forced by the same large-scale conditions (Figure 16b). 4CO2a water near the CP coast is only $\sim 10 \%$ less stratified than in $4 \mathrm{CO} 2$, due to the stronger upwelling-favorable wind stress in 4CO2a. Consequently, the source water depths present a shoaling in both simulations compared to PI, and are $\sim 10 \%$ shallower in 4CO2 (Figure 15c) than in 4CO2a. Thus, the increase in stratification accounts for the upwelling of shallower source waters in 4CO2 than in PI (Figure 15c). This increase is mainly due to the enhanced stratification imposed by the large-scale circulation and heat fluxes, and is locally strengthened 


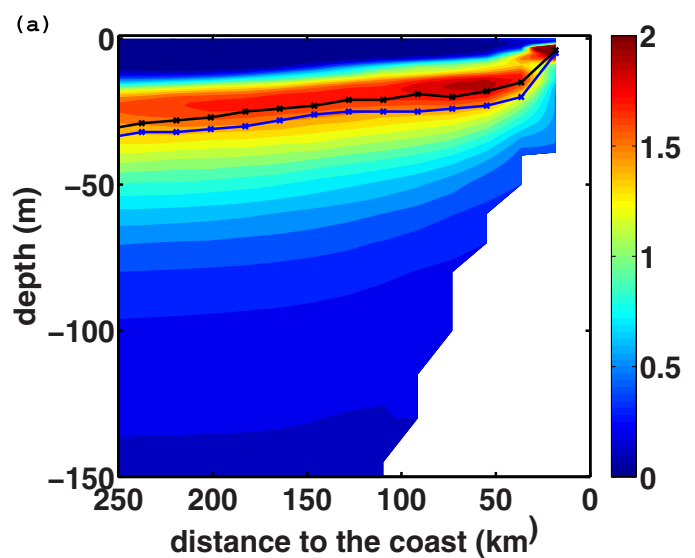

(b)

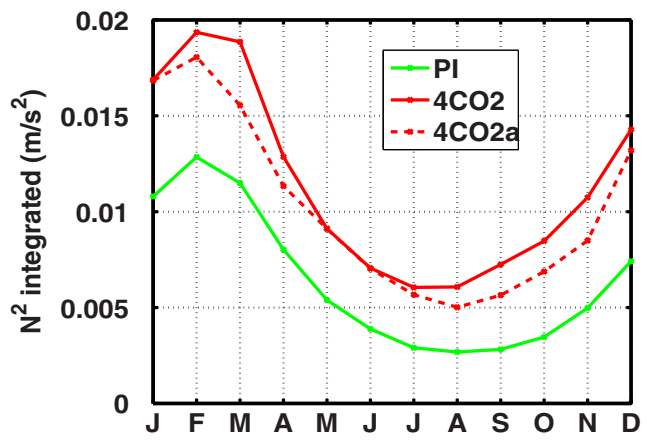

Figure 16. (a) Annual mean stratification difference $\left(\Delta N^{2}\right.$, with $N$ the Brunt-Väisälä frequency, in $\left.10^{-4} s^{-2}\right)$ between the $4 C O 2$ and PI simulations for a cross-shore section averaged between $7^{\circ} \mathrm{S}$ and $13^{\circ} \mathrm{S}$. The black (blue) line marks the 4CO2 (PI) pycnocline depth. (b) Seasonal cycle of $\int N^{2} \mathrm{dz}$ (in m s${ }^{-2}$ ), averaged over the shelf (area comprised between $7^{\circ} \mathrm{S}, 13^{\circ} \mathrm{S}$, the coast and the $200 \mathrm{~m}$ isobath) and integrated between the surface and $150 \mathrm{~m}$ depth, for the $\mathrm{Pl}$ and $4 \mathrm{CO} 2$ simulations.

by the decreased upwelling. Late austral summer to fall is the period with the smallest differences between $\mathrm{PI}$ and 4CO2 (Figure 15c). At this time of year, the dynamical forcing of the upwelling (i.e., coastal horizontal divergence and Ekman pumping, see sections 3.3.1 and 3.3.2) are unchanged with global warming, resulting in a similar source water depth.

\section{Discussion and Conclusions}

The evolution of the PCCS under 3 climate change scenarios corresponding to PI and increased atmospheric $\mathrm{CO}_{2}$ concentration is studied using a dynamical downscaling of the IPSL-CM4 CGCM. Alongshore ocean circulation presents an intensification of the poleward subsurface PCUC as well as a shoaling of the surface equatorward PCC when regional warming increases. Such changes, also found in the modeling study of EC2012, lead to an enhanced mesoscale eddy activity. A cross-shore horizontal mass balance in the Ekman layer close to the coast is used to diagnose coastal upwelling. It shows that the mean offshore transport associated with coastal upwelling decreases in the $2 \mathrm{CO} 2$ and $4 \mathrm{CO} 2$ scenarios with respect to the PI scenario, except during a few months in late austral summer. Thus, according to EC2012 and the present findings, Bakun's [1990] hypothesis that wind-driven upwelling should increase in EBUS under climate change is not verified in the Peru region for the climate scenarios we investigated. Our results are supported by trends in other large-scale coupled models than IPSL-CM4. In particular, BEL2014 showed that the IPSL-CM4 alongshore wind negative trend in the CP region is shared by the majority of 12 AR4 CGCM and by the multimodel mean.

One remarkable result of our study is the strong surface warming of Peruvian waters and, to a lesser extent, of Chilean waters, which contrast with the cooling trend observed over the last decades. Indeed, using observations and atmospheric model reanalyses in the central Chile region, Falvey and Garreaud [2009] found a cooling trend extending north to the Peru coast. Gutierrez et al. [2011] analyzed SST time series derived from sediments proxies and from observational SST at piers and confirmed the cooling trend off Peru in the last 50 years.

The observed nearshore SST cooling off Peru could be explained by an enhanced upwelling, driven by an alongshore wind intensification as shown by Bakun [1990] using ICOADS data. Nevertheless, these wind measurements were partly biased due to the increase in anemometer height on ships over the years [Tokinaga and Xie, 2011], and corrected data no longer show a clear increasing trend in the Peru region [see Tokinaga and Xie, 2011, Figure 1]. Differences between the observed cooling trend and our results can be explained by various reasons: first, the observed trend could be due to multidecadal variability, which is filtered in our modeling framework based on the analysis of the seasonal climatological cycle under radically different climates. Second, discrepancies between our results and observed trends might also be due to the resolution $(50 \mathrm{~km}$ ) of our downscaled atmospheric product, which could still be too coarse to correctly force the nearshore upwelling dynamics. For example, a model with a higher spatial resolution may allow to better represent the wind drop-off near the coast [e.g., Renault et al., 2012], modifying the respective roles of Ekman pumping and Ekman transport, and potentially the SST trends. Finally, the feedback of SST on 
surface wind was not taken into account in our so-called forced ocean model set up. Introducing this effect might modify land-sea and alongshore pressure gradients [Bakun, 1990], impacting the coastal wind, and hence upwelling and mesoscale activity [Perlin et al., 2006; Jin et al., 2009]. Using a coupled model simulating these processes is, however, beyond the scope of the present study and reserved for future work.

Note that, in a modeling study, Aiken et al. [2011] also found a SST cooling of $\sim 2^{\circ} \mathrm{C}$ in austral summer off the Chilean coasts, using the downscaled wind forcing from the A2 SRES scenario, whereas we found a 4-5 C SST increase in 4CO2 (Figure 9b) in spite of an upwelling strengthening (figure not shown). These opposed trends could be explained by the fact that they used oceanic initial and boundary conditions corresponding to present climate (World Ocean Atlas climatology). Thus, their climate-change simulations did not take into account the impact of global warming on the large-scale oceanic stratification in the PCCS, whereas ours do.

Our results can be compared with those of EC2012. They are not independent as the same CGCM (IPSLCM4) was downscaled, using different methods. The statistical downscaling of surface winds performed by GO2011, which is computationally less costly than the dynamical downscaling method, is based on the strong hypothesis that the statistical relation between large-scale atmospheric patterns (from NCEP reanalysis) and Peru-Chile surface winds (from QuikSCAT) is not modified by global warming. EC2012's and our study show that the mesoscale dynamics forced by dynamically and statistically downscaled atmospheric fields have common trends, which is encouraging for the use of statistical downscaling methods. This is in line with results of Cambon et al. [2013], who showed a good agreement between the modeled ocean circulation forced by statistically downscaled winds and by observed winds over the 1992-2000 time period. However, modifications of the wind stress seasonal cycle of GO2011 and BEL2014 differ: GO2011 presents a moderate austral winter strengthening and an austral summer weakening, contrasting with our year-round decrease (Figure 11a). As expected, the seasonal cycle of coastal upwelling is impacted by the wind changes: while EC2012 evidenced a moderate austral winter increase (5-10\%) and a 10-20\% decrease during austral summer from PI to 4CO2 (see Figure 8b in EC2012), our simulations show a clear decrease from May to February (from $\sim 15 \%$ in May to $\sim 70 \%$ in December) and almost no austral summer increase (Figure 11b). In EC2012, the modifications in the upwelling seasonal cycle are directly related to those of the wind stress, while our simulations show that changes in cross-shore geostrophic transport play an important role, as it compensates entirely the (austral) summer Ekman transport decrease. This comparison underlines differences between statistical (EC2012) and dynamical (this study) downscaling, pointing to the need for further studies to reduce the uncertainty in nearshore wind stress changes.

Our results show that compensation of coastal upwelling by cross-shore geostrophic currents is an important process, which needs to be taken into account [Colas et al., 2008; Marchesiello and Estrade, 2010]. In all of our simulations, the onshore geostrophic velocity plays an important role all year round and compensates up to one third of the Ekman transport (Figure 11). During late austral summer in the 4CO2 scenario off Peru, the Ekman transport is weaker than in Pl. However, the onshore geostrophic flow decreases between January and April in 4CO2, compensating the wind weakening, and resulting in a total upwelling similar to PI. The important message here is that the upwelling late summer evolution could not have been deduced solely from Ekman transport changes.

In addition, Ekman pumping (derived from wind stress) is often used to infer vertical fluxes of nutrients in the coastal transition zone [e.g., Chavez and Messié, 2009] and has been linked to zooplankton decadal variability in upwelling systems [e.g., Rykaczewski and Checkley, 2008 in the California EBUS]. Our results show that the often-neglected geostrophic vertical velocity may contribute to up to $30 \%$ of the total vertical flux at the Ekman layer depth. In our projections, the vertical flux increases moderately in the austral latesummer and early-spring seasons (Figures 14a-14c), whereas Ekman pumping decreases. In conclusion, upwelling indices from Ekman pumping and divergence of Ekman transport at the coast derived from atmospheric model fields are not sufficiently accurate, and oceanic regional simulations are essential to take into account the regulating role of geostrophic currents.

Changes in mesoscale eddy activity may have a strong influence on biological activity at long time scales, particularly on nearshore larval retention patterns and connectivity [e.g., Aiken et al., 2011; Brochier et al., 2013]. The increase in EKE found in this study does not vary linearly with respect to the intensity of the greenhouse effect: the $2 \mathrm{CO} 2$ simulation presents a slightly more intense mesoscale activity than the $4 \mathrm{CO} 2$ simulation (see Table 3). The impact of climate change may thus be very strong even under less extreme 


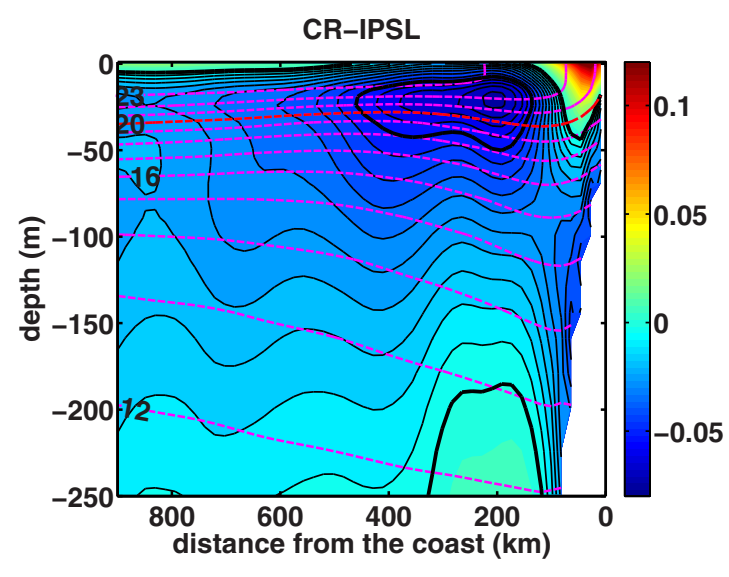

Figure A1. Annual mean alongshore velocities (shading, in $\mathrm{m} \mathrm{s}^{-1}$ ) and temperature (dashed line, in ${ }^{\circ} \mathrm{C}$ ) averaged between $7^{\circ} \mathrm{S}$ and $13^{\circ} \mathrm{S}$ for CR-IPSL. Thin black contour interval is $0.5 \mathrm{~cm} \mathrm{~s}^{-1}$., and black bold contours are 0 and $-5 \mathrm{~cm} \mathrm{~s}^{-1}$ velocities. Temperature contour interval is $1{ }^{\circ} \mathrm{C}$ and red-dashed line marks the $20^{\circ} \mathrm{C}$ isotherm. scenarios than the 4CO2. Off Chile, the increase is also larger in 2CO2 than in 4CO2. EC2012 found an increase in EKE, but it was higher in $4 \mathrm{CO} 2$ than in 2CO2 off Peru and Central Chile (see Table 3). However, these values are twice as high as those from our study and the patterns appear in slightly different locations, which makes the comparison difficult. Note also that EC2012 used daily wind forcing while we used monthly forcing, which reduces EKE in our case.

The changes in upwelling intensity and source water depth evidenced in our projections could also have a tremendous impact on the ecosystem productivity. Indeed, our simulations show that the annual mean upwelling intensity decreases and that the upwelling source waters are shallower under intensified surface warming.

Both effects may lead to a decrease in surface layer nutrient concentration, which could decrease primary productivity. McGowan et al. [2003] investigated the processes driving a decrease in source waters nutrient load during the Californian warm shift in 1976/1977. During the shift, alongshore coastal wind and wind stress curl increased but nutrient concentration decreased in the upper layer. They showed that the enhanced stratification and the deepening of the thermocline were responsible for the evolution of biogeochemical conditions. Using a regional ocean model, Chhak and Di Lorenzo [2007] reproduced the shoaling of the source waters during the warm phase of the shift, resulting mainly from the large-scale wind changes. These studies suggest that a stratification increase due to either surface heating and/or large-scale wind changes may have a negative influence on the nutrient enrichment of surface water. In our case, both the wind forcing decrease and stratification increase may contribute to a decrease in the nutrient supply off Peru. Besides, note that the

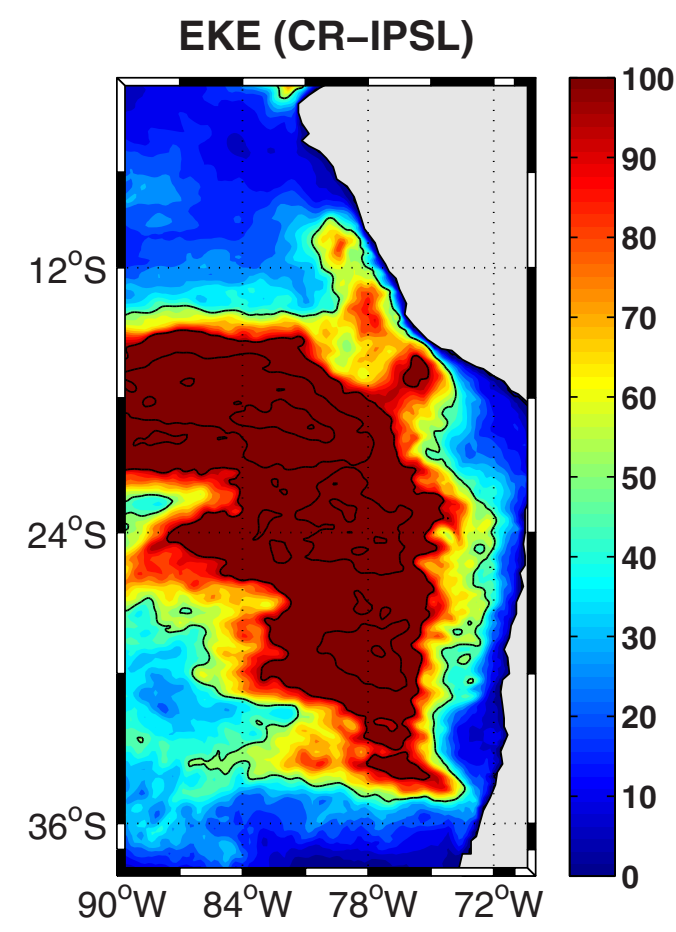

Figure A2. Annual mean eddy kinetic energy (EKE, in $\mathrm{cm}^{2} \mathrm{~s}^{-2}$ ) from CR-IPSL. Contour interval is $50 \mathrm{~cm}^{2} \mathrm{~s}^{-2}$. annual cycle of productivity off Peru is $180^{\circ}$ out of phase with the upwelling intensity, suggesting that light availability and wind mixing limit phytoplankton blooms in austral winter time [Echevin et al., 2008; Gutiérrez et al., 2011]. Therefore, during the main upwelling season, a shoaling of the mixed layer due to the wind decrease could mitigate the impact of the reduced upwelling of subsurface nutrients on biological productivity. Coupling a biogeochemical model to our oceanic model in future studies would allow investigating in greater detail the climate-change induced biogeochemical trends [e.g., Franks et al., 2013].

Our modeling approach presents some limitations. First, the atmospheric forcing was built by adding model fields from climate projections and observational climatologies (SCOW for winds and COADS for heat fluxes) as in Bruyere et al. [2014], assuming that the bias will remain identical under climate change conditions. Thus, the seasonal anomalies are not consistent with the mean state of the forcing. Besides, a corollary result of our study is that the direct forcing of the ocean circulation by LMDz downscaled atmospheric fields, which seems quite realistic (Figure 2), introduces nonetheless a 


\section{QAGU Journal of Geophysical Research: Oceans}

substantial bias in the modeled ocean circulation (Figures $4 \mathrm{~b}$ and $5 \mathrm{~b}$ ). Part of this bias (e.g., the position of the SEP anticyclone) is likely inherent to the large-scale atmospheric circulation simulated by LMDz. In this work, we assumed that our projections would be more robust by using an ad hoc corrected surface forcing (see section 2.3) to reduce the bias. We can conclude that significant improvements of the state-of-the-art regional and global atmospheric (and coupled) GCMs are necessary before we can use surface wind fields from these modeling systems without ad hoc corrections to force regional oceanic simulations.

Other EBUS may show different trends due to climate change than the ones in the PCCS. In the California system, Snyder et al. [2003] and Diffenbaugh et al. [2004] evidenced an increase in upwelling-favorable winds under global warming scenarios, consistently with the coastal wind strengthening and SST decrease observed during the last 30 years [García-Reyes and Largier, 2010]. Using the NCEP and ERA40 reanalysis in addition to the ICOADS database, Narayan et al. [2010] confirmed Bakun's [1990] trends showing a steady increase in intensity over the period 1960-2001 in the four major EBUS. Note, however, that the realism of wind and proxy-derived temperature trends is subject to debate in the North-West African system [Barton et al., 2013]. Regional climate modeling studies are undoubtedly of great help to better understand the physical processes driving the trends of the last decades.

\section{Acknowledgments}

This work is a contribution to the cooperative agreement between the Instituto del Mar del Peru (IMARPE) and the Institut de Recherche et de Developpement (IRD), and of the Laboratoire Mixte International (LMI) Dynamiques du système du Courant de Humboldt (DISCOH). V. Oerder and F. Colas were sponsored by the Agence Nationale de la Recherche PEPSVMCS2008 and PULSATION-11-MONU010 projects. V. Oerder stay at IMARPE was partly funded by a grant "Aide à la mobilité internationale des étudiants" from lle-de- France region. Simulations were performed on the Cratos and Adonis servers hosted at LOCEAN and using HPC resources from GENCI-IDRIS (projects i2011011140 and x2012016895). Christophe Hourdin is acknowledged for his help in implementing and running the model on the various servers. Patrick Marchesiello and Ivonne Montes are acknowledged for helpful discussion. Alexis Chaigneau is acknowledged for providing current observations. The Instituto del Mar del Peru (IMARPE) is acknowledged for hosting V. Oerder at the Laboratorio de Modelado Oceanografico, ecosistemico y del cambio climatico (LMOECC). Jorge Ramos is acknowledged for his help in running ROMS-offline at LMOECC. The altimeter products were produced by SSALTO-DUACS and distributed by AVISO with support from CNES. The AVHRR-Pathfinder SST data were obtained from the Physical Oceanography Distributed Active Archive Center (PO.DAAC) at the NASA Jet Propulsion Laboratory. The CARS climatology is from the CSIRO Marine Laboratories (www.cmar.csiro.au/cars). The SCOW scatterometer wind stress data can be downloaded at http://cioss. coas.oregonstate.edu/scow/. Numerical data analyzed in this article were obtained by models experiments described in section 2 . Contact the corresponding author for more information (vera.oerder@loceanipsl.upmc.fr).

\section{Appendix A: Regional Ocean Response to Coarse-resolution Climate Model Forcing}

We comment here results from a ROMS simulation forced by the coarse resolution IPSL wind forcing (CRIPSL). The alongshore flow displays unrealistic features such as a very weak undercurrent, and a very strong offshore countercurrent (Figure A1), in comparison with features described in the literature [e.g., Chaigneau et al., 2013] (Figure 4c). The spatial pattern of EKE (Figure A2) is displaced away from the coast and the intensity is far too high in comparison with EKE derived from AVISO (Figure 5c). Similar unrealistic results were described by Colas et al. [2012] and Cambon et al. [2013] using the coarse resolution NCEP winds as wind forcing. This clearly justifies our downscaling approach based on the use of surface winds from the LMDz-ESP05 model described in detail in BEL2014.

\section{References}

Aiken, C. M., S. A. Navarrete, and J. L. Pelegri (2011), Potential changes in larval dispersal and alongshore connectivity on the central Chilean coast due to an altered wind climate, J. Geophys. Res., 116, G04026, doi:10.1029/2011JG001731.

Albert, A., V. Echevin, M. Lévy, and O. Aumont (2010), Impact of nearshore wind stress curl on coastal circulation and primary productivity in the Peru upwelling system, J. Geophys. Res., 115, C12033, doi:10.1029/2010JC006569.

Bakun, A. (1990), Global climate change and intensification of coastal ocean upwelling, Science, 247, 198-201, doi:10.1126/ science.247.4939.198.

Bakun, A., and C. Nelson (1991), The seasonal cycle of wind-stress curl in subtropical eastern boundary current regions, J. Phys. Oceanogr., 21(12), 1815-1833, doi:10.1175/1520-0485(1991)021<1815:TSCOWS > 2.0.CO;2.

Barton, E. D., B. D. Field, and C. Roy (2013), Canary current upwelling: More or less?, Prog. Oceanogr., 116, 167-178, doi:10.1016/ j.pocean.2013.07.007.

Belmadani, A., V. Echevin, B. Dewitte, and F. Colas (2012), Equatorially forced intraseasonal propagations along the Peru-Chile coast and their relation with the nearshore eddy activity in 1992-2000: A modeling study, J. Geophys. Res., 117, C04025, doi:10.1029/ $2011 \mathrm{JC} 007848$.

Belmadani, A., V. Echevin, F. Codron, K. Takahashi, and C. Junquas (2014), What dynamics drive future winds scenarios off Peru and Chile?, Clim. Dyn., 43(7-8), 1893-1914, doi:10.1007/s00382-013-2015-2.

Blanke, B., and S. Raynaud (1997), Kinematics of the Pacific equatorial undercurrent: An Eulerian and Lagrangian approach from GCM results, J. Phys. Oceanogr., 27, 1038-1053, doi:10.1175/1520-0485(1997) 027<1038:KOTPEU>2.0.CO;2.

Boé, J., A. Hall, F. Colas, J. McWilliams, X. Qu, J. Kurian, and S. Kapnic (2011), What shapes mesoscale wind anomalies in coastal upwelling zones?, Clim. Dyn., 36, 2037-2049, doi:10.1007/s00382-011-1058-5.

Brink, K. H. (1982), The effect of bottom friction on low-frequency coastal trapped waves, J. Phys. Oceanogr., 12, 127-133, doi:10.1175/ 1520-0485(1982)012<0127:TEOBFO>2.0.CO;2.

Brochier, T., V. Echevin, J. Tam, A. Chaigneau, K. Goubanova, and A. Bertrand (2013), Climate change scenario experiment predict a future reduction in small pelagic fish recruitment in the Humboldt Current system, Global Change Biol., 19, 1841-1853, doi:10.1111/gcb.12184.

Bruyere, C. L., J. M. Done, G. J. Holland, and S. Fredrick (2014), Bias corrections of global models for regional climate simulations of highimpact weather, Clim. Dyn., 43, 1847-1856, doi:10.1007/s00382-013-2011-6.

Cambon, G., K. Goubanova, P. Marchesiello, B. Dewitte, and S. Illig (2013), Assessing the impact of downscaled winds on a regional ocean model simulation of the Humboldt system, Ocean Modell., 65, 11-24, doi:10.1016/j.ocemod.2013.01.007.

Capet, X. J., P. Marchesiello, and J. C. McWilliams (2004), Upwelling response to coastal wind profiles, Geophys. Res. Lett., 31, L13311, doi: 10.1029/2004GL020123.

Chaigneau, A., N. Dominguez, G. Eldin, L. Vasquez, R. Flores, C. Grados, and V. Echevin (2013), Near-coastal circulation in the Northern Humboldt Current System from shipboard ADCP data, J. Geophys. Res. Oceans, 118, 5251-5266, doi:10.1002/jgrc.20328.

Chavez, F. P., and M. Messié (2009), A comparison of eastern boundary upwelling ecosystems, Prog. Oceanogr., 83, 80-96, doi:10.1016/ j.pocean.2009.07.032. 
Chavez, F., A. Bertrand, R. Guevara-Carrasco, P. Soler, and J. Csirke (2008), The northern Humboldt Current System : Brief history, present status and a view towards the future, Prog Oceanogr., 79, 95-105, doi:10.1016/j.pocean.2008.10.012.

Chhak, K., and E. Di Lorenzo (2007), Decadal variations in the California Current upwelling cells, Geophys. Res. Lett., 34, L14604, doi:10.1029/ 2007 GL030203.

Colas, F., X. Capet, J. C. McWilliams, and A. Shchepetkin (2008), 1997-1998 El Niño off Peru: A Numerical study, Prog. Oceanogr., 79(2), 138155, doi:10.1016/j.pocean.2008.10.015.

Colas, F., J. C. Mcwilliams, X. Capet, and J. Kurian (2012), Heat balance and eddies in the Peru-Chile current system, Clim. Dyn., 39(1-2), 509529, doi:10.1007/s00382-011-1170-6.

DaSilva, A., C. Young, and S. Levitus (1994), Atlas of Surface Marina Data 1994, vol. 1, Algorithms and Procedures, NOAA, Silver Spring, Md.

Diffenbaugh, N. S., M. A. Snyder, and L. C. Sloan (2004) Could CO2-induced land-cover feed-backs alter near-shore upwelling regimes?, Proc. Natl. Acad. Sci. U. S. A., 101, 27-32, doi:10.1073/pnas.0305746101.

Echevin, V., O. Aumont, J. Ledesma, and G. Flores (2008), The seasonal cycle of surface chlorophyll in the Peruvian upwelling system: A modeling study, Progr. Oceanogr., 79, 167-176, doi:10.1016/j.pocean.2008.10.026.

Echevin, V., F. Colas, A. Chaigneau, and P. Penven (2011), Sensitivity of the Northern Humboldt Current System nearshore modeled circulation to initial and boundary conditions, J. Geophys. Res., 116, C07002, doi:10.1029/2010JC006684.

Echevin, V., K. Goubanova, A. Belmadani, and B. Dewitte (2012), Sensitivity of the Humboldt current system to global warming: A downscaling experiment from the ipsl-cm4 model, Clim. Dyn., 38(3-4), 761-774, doi:10.1007/s00382-011-1085-2.

Falvey, M., and R. Garreaud (2009), Regional cooling in a warming world: Recent temperature trends in the southeast Pacific and along the west coast of subtropical South America (1979-2006), J. Geophys. Res., 114, D04102, doi:10.1029/2008JD010519.

Franks, P. J. S., E. Di Lorenzo, N. L. Goebel, F. Chenillat, P. Riviere, C. A. Edward, and A. J. Miller (2013), Modeling physical-biological responses to climate change in the California Current system, Oceanography, 26, 26-33, doi:10.5670/oceanog.2013.42.

García-Reyes, M., and J. Largier (2010), Observations of increased wind-driven coastal upwelling off central California, J. Geophys. Res., 115, C04011, doi:10.1029/2009JC005576.

Garreaud, R., and M. Falvey (2008), The coastal winds off western subtropical South America in future climate scenarios, Int. J. Climatol., 29, 543-554, doi:10.1002/joc.1716.

Goubanova, K., V. Echevin, B. Dewitte, F. Codron, K. Takahashi, P. Terray, and M. Vrac (2011), Statistical downscaling of sea surface wind over the Peru-Chile upwelling region: Diagnosing the impact of climate change from the ipsl-cm4 model, Clim. Dyn., 36, 1365-1378, doi:10.1007/s00382-010-0824-0.

Guillen, O., and R. Calienes (1981), Productividad y afloramiento frente a las aguas costeras peruanas, Bol. Inst. Mar Peru, Callao, Vol. Extraordinario, 131-144.

Guilyardi, E. (2006), El Nino-mean state-seasonal cycle interactions in a multi-model ensemble, Clim. Dyn., 26, 329-348, DOI 10.1007/ s00382-005-0084-6.

Gutiérrez, D., et al. (2011), Coastal cooling and increased productivity in the main upwelling zone off Peru since the mid-twentieth century, Geophys. Res. Lett., 38, L07603, doi:10.1029/2010GL046324.

Hourdin, F., et al. (2006), The LMDZ4 general circulation model: Climate performance and sensitivity to parametrized physics with emphasis on tropical convection, Clim. Dyn., 27(7-8), 787-813, doi:10.1007/s00382-006-0158-0.

Hurrell, J., J. Hack, D. Shea, J. Caron, and J. Rosinski (2008), A new sea surface temperature and sea ice boundary dataset for the community atmosphere model, J. Clim., 21, 5145-5153, doi:10.1175/2008JCLI2292.1.

Jin, X., C. Dong, J. Kurian, J. C. McWilliams, D. B. Chelton, and Z. Li (2009), SST/wind interaction in coastal upwelling: Oceanic simulation with empirical coupling, J. Phys. Oceanogr., 39(11), 2957-2970, doi:10.1175/2009JPO4205.1.

Jones, R. G., M. Noguer, D. C. Hassell, D. Hudson, S. S. Wilson, G. J. Jenkins, and J. F. B. Mitchell (2004), Generating High Resolution Climate Change Scenarios Using PRECIS, 40 pp., Met. Office Hadley Cent., Exeter.

Kang, S. M., and J. Lu (2012), Expansion of the Hadley cell under global warming: Winter versus summer, J. Clim., 25, 8387-8393, doi: 10.1175/JCLI-D-12-00323.1.

Kilpatrick, K. A., G. P. Podestá, and R. Evans (2001), Overview of the NOAA/NASA advanced very high-resolution radiometer Pathfinder algorithm for sea surface temperature and associated matchup database, J. Geophys. Res., 106(C5), 9179-9197, doi:10.1029/1999JC000065.

Lentz, S. J., and D. C. Chapman (2004), The importance of non-linear cross-shelf momentum flux during wind-driven coastal upwelling, J. Phys. Oceanogr., 34, 2444-2457, doi:10.1175/JPO2644.1.

Liu, W. T., K. B. Katsaros, and J. A. Businger (1979) Bulk parameterization of the air-sea exchange of heat and water vapor including the molecular constraints at the interface, J. Atmos. Sci., 36, 1722-1735, doi:10.1175/1520-0469(1979)036<1722:BPOASE $>2.0 . C O ; 2$.

Madec, G., P. Delecluse, M. Imbard, and C. Levy (1998), OPA version 8.1 Ocean General Circulation Model Reference Manual, Note du Pole de Modélisation, 11, 91 pp., Inst. Pierre et Simon Laplace (IPSL), France.

Marchesiello, P., and P. Estrade (2010), Upwelling limitation by geostrophic onshore flow, J. Mar. Res., 68, 37-62, doi:10.1357/ 002224010793079004.

Marti, O., P. Braconnot, J.-L. Dufresne, J. Bellier, R. Benshila, S. Bony, P. Brockmann, P. Cadule, A. Caubel, and F. Codron (2010), Key features of the IPSL ocean atmosphere model and its sensitivity to atmospheric resolution, Clim. Dyn., 34(1):1-26, doi:10.1007/s00382009-0640-6.

Mason, E., F. Colas, and J. L. Pelegri (2012), A Lagrangian study tracking water parcel origins in the Canary upwelling system, Sci. Mar., 76S1, 79-84, doi:10.3989/scimar.03608.18D.

McGowan, J. A., S. J. Bograd, R. J. Lynn, and A. J. Miller (2003), The biological response to the 1977 regime shift in the California Current, Deep Sea Res., Part II, 50, 2567-2582, doi:10.1016/s0967-0645(03)00135-8.

Montes, I., F. Colas, X. Capet, and W. Schneider (2010), On the pathways of the equatorial subsurface currents in the eastern equatorial Pacific and their contributions to the Peru-Chile Undercurrent, J. Geophys. Res., 115, C09003, doi:10.1029/2009JC005710.

Nakicenovic, N., et al. (2000), Special Report on Emissions Scenarios: A Special Report of Working Group III of the Intergovernmental Panel on Climate Change, 599 pp., Cambridge Univ. Press, Cambridge.

Narayan, N., A. Paul, S. Mulitza, and M. Schulz (2010), Trends in coastal upwelling intensity during the late 20th century, Ocean Sci. Discuss., 6, 815-823, doi:10.5194/os-6-815-2010.

Pascual, A., Y. Faugere, G. Larnicol, and P. Le Traon (2006), Improved description of the ocean mesoscale variability by combining four satellite altimeters, Geophys. Res. Lett., 33, L02611, doi:10.1029/2005GL024633.

Pedloski, J. (1996), Ocean Circulation Theory, pp. 453, Springer, Berlin.

Penven, P., V. Echevin, J. Pasapera, F. Colas, and J. Tam (2005), Average circulation, seasonal cycle, and mesoscale dynamics of the Peru Current System: A modeling approach, J. Geophys. Res., 110, C10021, doi:10.1029/2005JC002945. 
Perlin, N., E. D. Skyllingstad, R. M. Samelson, and P. L. Barbour (2006), Numerical simulation of Air-Sea coupling during coastal upwelling, J. Phys. Oceanogr., 37, 2081-2093, doi:10.1175/JPO3104.1.

Pizarro, O., A. J. Clarke, and S. Van Gorder (2001), El Niño sea level and currents along the South American coast: Comparison of observations with theory, J. Phys. Oceanogr., 31, 1891-1903, doi:10.1175/1520-0485(2001)031<1891:ENOSLA >2.0.CO;2.

Renault, L., B. Debitte, P. Marchesiello, S. Illig, V. Echevin, G. Cambon, M. Ramos, O. Astudillo, P. Minnis, and J. K. Ayers (2012), Upwelling response to atmospheric coastal jets off central Chile: A modeling study of the October 2000 event, J. Geophys. Res., 117, C02030, doi: 10.1029/2011JC007446.

Risien, C., and D. Chelton (2008), A global climatology of surface wind and wind stress fields from eight years of Quikscat scatterometer data, J. Phys. Oceanogr., 38, 2379-2413, doi:10.1175/2008JPO3881.1.

Rivas, D., and R. M. Samelson (2010), A numerical modeling study of the upwelling sources waters along the Oregon coast during $2005, J$. Phys. Oceanogr., 41, 88-102, doi:10.1175/2010JPO4327.1.

Roemmich, D., and J. McGowan (1995), Climatic warming and the decline of zooplankton in the California current, Nature, 267, 1324-1326, doi:10.1126/science.267.5202.1324.

Rykaczewski, R., and D. Checkley (2008), Influence of winds on the pelagic ecosystem in upwelling regions, Proc. Natl. Acad. Sci. U. S. A., 105(6), 1965-1970, doi:10.1073/pnas.0711777105.

Rykaczewski, R. R., and J. P. Dunne (2010), Enhanced nutrient supply to the California Current Ecosystem with global warming and increased stratification in an earth system model, Geophys. Res. Lett., 37, L21606, doi:10.1029/2010GL045019.

Shchepetkin, A. F., and J. C. McWilliams (2005), The regional oceanic modeling system: A split explicit free-surface topography-followingcoordinate ocean model, Ocean Modell., 9, 347-404, doi:10.1016/j.ocemod.2004.08.002.

Shchepetkin, A. F., and J. C. McWilliams (2009), Correction and commentary for "Ocean Forecasting in Terrain-Following Coordinates: Formulation and Skill Assessment of the Regional Ocean Modeling System" by Haidvogel et al., J. Comput. Phys., 227, pp. 3595-3624. J. Comput. Phys., 228, 8985-9000, doi:10.1016/j.jcp.2009.09.002.

Smith, W. H. F., and D. T. Sandwell (1997), Global seafloor topography from satellite altimetry and ship depth soundings, Science, 277, 1956-1962, doi:10.1126/science.277.5334.1956.

Snyder, M. A., L. C. Sloan, N. S. Diffenbaugh, and J. L. Bell (2003), Future climate change and upwelling in the California Current, Geophys. Res. Lett., 30(15), 1823, doi:10.1029/2003GL017647.

Song, H., A. J. Miller, B. D. Cornuelle, and E. Di Lorenzo (2011), Changes in upwelling and its water sources in the California Current System driven by different wind forcing, Dyn. Atmos. Oceans., 52, 170-191, doi:10.1016/j.dynatmoce.2011.03.001.

Steinacher, M., et al. (2010), Projected 21st century decrease in marine productivity: A multi-model analysis, Biogeosciences, 7, 979-1005, doi:10.5194/bg-7-979-2010.

Tokinaga, H., and S. P. Xie (2011), Wave and anemometer-based sea-surface wind (WASWind) for climate change analysis, J. Clim., 24, 267285, doi:10.1175/2010JCLI3789.1.

Vecchi, G. A., and B. J. Soden (2007), Global warming and the weakening of tropical circulation, J. Clim., 20, 4316-4340, doi:10.1175/ JCLI4258.1.

Wyant, M. C., et al. (2010), The PreVOCA experiment: Modeling the lower troposphere in the Southeast Pacific, Atmos. Chem. Phys., 10, 4453-5010, doi:10.5194/acp-10-4757-2010. 